This item was submitted to Loughborough's Research Repository by the author.

Items in Figshare are protected by copyright, with all rights reserved, unless otherwise indicated.

\title{
Time-varying managerial overconfidence and pecking order preference
}

\section{PLEASE CITE THE PUBLISHED VERSION}

https://doi.org/10.1007/s11156-017-0647-8

\section{PUBLISHER}

(c) Springer

\section{VERSION}

AM (Accepted Manuscript)

\section{PUBLISHER STATEMENT}

This work is made available according to the conditions of the Creative Commons Attribution-NonCommercialNoDerivatives 4.0 International (CC BY-NC-ND 4.0) licence. Full details of this licence are available at: https://creativecommons.org/licenses/by-nc-nd/4.0/

\section{LICENCE}

CC BY-NC-ND 4.0

\section{REPOSITORY RECORD}

Vivian, Andrew, and Bin Xu. 2017. "Time-varying Managerial Overconfidence and Pecking Order Preference". figshare. https://hdl.handle.net/2134/25375. 


\title{
Time-varying Managerial Overconfidence and Pecking Order Preference
}

\begin{abstract}
This paper examines whether managerial overconfidence enhances or weakens pecking order preference. We construct time-varying managerial words-based (i.e. tone of Chairman's Statement) and action-based (i.e. firm investment and directors' trading) overconfidence measures. Both optimistic tone and industry-adjusted investment have significant and negative impacts on the pecking order coefficient in the Shyam-Sunder and Myers (1999) regression framework. Overconfident managers tend to use more equity than debt to finance deficits. This new evidence is consistent with the proposition that overconfident managers who underestimate the riskiness of future earnings believe that their debt (equity) is undervalued (overvalued) and therefore prefer equity to debt financing. Thus, managerial overconfidence can lead to a reverse pecking order preference. We also find that managerial overconfidence significantly weakens pecking order preference especially in firms with high earnings volatility and small firms.
\end{abstract}

Keywords: managerial overconfidence, pecking order preference, optimistic tone.

JEL classification: G30, G32, G02 


\section{Introduction}

The pecking order theory of capital structure suggests that firms prefer internal to external financing and if the internal funds are not sufficient debt is preferred to equity (Donaldson, 1961; Myers, 1984; Myers and Maljuf, 1984). Empirical evidence on the pecking order predictions is mixed. Shyam-Sunder and Myers (1999) propose a test of pecking order theory and find it outperforms the static trade-off theory. In contrast, using a larger sample, Frank and Goyal (2003) do not find strong evidence for the pecking order theory. They report a "pecking order puzzle (size anomaly)" ${ }^{1}$ that larger firms, which are relatively less subject to the information asymmetry, exhibit more pecking order behaviour. This finding is inconsistent with the pecking order model based on information asymmetry. This study contributes to the literature on the pecking order puzzle by examining the effect of managerial overconfidence on the pecking order preference; it demonstrates empirically that highly overconfident managers follow pecking order behaviour less closely than more rational managers. Overconfident managers tend to use more equity than debt to finance deficits.

To reconcile the pecking order puzzle, it is important to recognize that pecking order theory is a conditional theory (Myers, 2001). The most commonly cited condition for pecking order is perhaps Myers and Majluf's (1984) adverse selection ${ }^{2}$. However, pecking order theory can be regarded as a "funding preference theory" rather than a pure adverse selection problem (Welch, 2006). The pecking order may arise if issuing more junior securities is

\footnotetext{
${ }^{1}$ De Jong et al. (2010) refer to Frank and Goyal's (2003) finding that firm size is positively related to the degree of pecking order as pecking order puzzle or size anomaly.

${ }^{2}$ The Myers-Majluf (1984) type model shows that the pecking order is conditional on the asymmetric information between managers and outside investors. Managers with more inside information are reluctant to use external financing, especially the equity, which is undervalued by the outsiders.
} 
relatively more costly. Thus, the adverse selection costs associated with information sensitive securities is only one of the potential drivers of pecking order. ${ }^{3}$

The behavioural finance literature suggests that managerial overconfidence can also drive pecking order preference (Shyam-Sunder and Myers, 1999; Graham and Harvey, 2001; Heaton, 2002; Hackbarth, 2008; Malmendier, Tate and Yan, 2011). Heaton (2002) shows that overconfident managers tend to believe they have positive inside information and their firm's stocks are therefore undervalued by the outsiders. This perceived asymmetric information associated with managerial overconfidence leads to a preference for debt over equity. The model provides a re-interpretation of the Myers-Maljuf (1984) model from actual information asymmetry to perceived information asymmetry being a driver of pecking order (Malmendier and Tate, 2005). ${ }^{4}$ Hackbarth’s (2008) model predicts an either standard or reverse pecking order for firms subject to two types of managerial overconfidence, namely growth perception bias and risk perception bias respectively. ${ }^{5}$ The reason why overconfident managers in Hackbarth's (2008) model may not follow a standard pecking order is that those managers especially with risk perception bias (i.e. underestimate the riskiness of earnings) believe that

\footnotetext{
${ }^{3}$ Similarly, Fama and French's (2005) study suggests that asymmetric information problems are neither the only nor perhaps even an important determinant of capital structure. They further argue that "any forces that cause firms to systematically deviate from pecking order financing imply that the pecking order, as the complete model of capital structure proposed by Myers (1984) and Myers and Majluf (1984), is dead”. Other potential conditions of pecking order include agency costs (Myers, 2003; Leary and Roberts, 2010), corporate taxes (Stiglitz, 1973; Hennessy and Whited, 2005) and transaction costs (Welch, 2006).

${ }^{4}$ Similarly, Malmendier, Tate and Yan (2011) develop a model of capital structure with overconfident managers who overestimate firms' mean future cash flow and therefore believe that their firms are undervalued by the market. Their model also predicts a pecking order preference arised from managerial overconfidence, conditional on raising risky external capital.

${ }^{5}$ The standard pecking order preference refers to a preference for debt over equity financing, In contrast, the reverse pecking order preference refers to a preference for equity over debt financing. Empirically, we expect that at least more than half of the financing deficit is financed by equity if a firm follows a reverse pecking order preference.
} 
the equity (debt) is overvalued (undervalued). Thus, whether managerial overconfidence enhances or weakens pecking order preference is an empirical question. ${ }^{6}$

We use modified Shyam-Sunder and Myers (SSM) (1999) regression to test the impact of managerial overconfidence on the pecking order preference. Specifically, our modified model is asymmetric so that we can empirically differentiate the impacts of managerial overconfidence on issuance and repurchase decisions, although our main focus is on the issuance decisions. Our three types of overconfidence measures are constructed based on computational linguistic analysis of UK Chairman's Statement (namely optimistic tone) ${ }^{7}$, industry-adjusted investment rate, and how executives (e.g. CEO and CFO) trade their own firms’ shares, respectively.

We find both optimistic tone and industry-adjusted investment have significant and negative impacts on the pecking order coefficient in the SSM (1999) regression framework, especially when there is financing deficit. These findings suggest that overconfident managers prefer equity to debt to meet external financing needs, meaning that managerial overconfidence leads to a reverse pecking order preference. Our evidence supports Hackbarth’s (2008) proposition that overconfident managers, who underestimate the riskiness of earnings ("risk perception bias"), tend to prefer equity to debt financing. We also find that the relation between managerial overconfidence and reverse pecking order preference is more pronounced for firms with higher earnings volatility, suggesting that "risk perception bias" is the underlying channel through which overconfidence leads to a reverse pecking order preference.

${ }^{6}$ Importantly, Hackbarth (2008) argues that the ambiguous effects of managerial overconfidence on the pecking order may shed light on the inconclusive cross-sectional findings on the standard pecking order prediction.

${ }^{7}$ There is an emerging literature that attempts to capture managerial overconfidence based on computational linguistic analysis of corporate disclosures (Ataullah et al., 2017; Hilary et al., 2016). 
Furthermore, we find the effect of overconfidence on the reverse pecking order preference is especially strong for small firms. Overconfident managers in small firms are reluctant to follow standard pecking order, in which case managerial overconfidence contributes to the pecking order puzzle (size anomaly) that small firms with higher information asymmetry surprisingly exhibit weaker pecking order preference relative to large firms. In addition, the effects of insider trading-based measures of managerial overconfidence are, however, relatively weak and less consistent, which is probably because insider (especially CEO) trading can be driven by information asymmetry and thus is not a perfect proxy for managerial overconfidence. Overall, this study supports the proposition that managerial overconfidence is an underlying driver of the reverse pecking order preference, which may explain the pecking order puzzle.

We proceed as follows. Section 2 describes pecking order tests and provides a review of tests of various pecking order conditions using modified SSM (1999) regression. Section 3 develops the hypotheses. Section 4 presents methodology and data. Section 5 discusses the empirical findings and section 6 concludes.

\section{Related literature and hypothesis development}

\subsection{Prior literature on the test of the pecking order theory}

Shyam-Sunder and Myers (SSM) (1999) propose an empirical model to test the pecking order theory. Specifically, they examine to what extent the net debt issues are driven by firm financing deficit (DEF). The static pecking order theory suggests that firms with external financing need use only debt to fund the deficit. The SSM regression can be written as: $\Delta D_{i t}=a+b_{P O} D E F_{i t}+e_{i t}$, where, $\Delta D_{i t}$ is the amount of debt issued or retired, $b_{P O}$ is the pecking order coefficient, $D E F_{i t}$ is the financing deficit. $b_{P O}$ is expected to be one under the strict pecking order theory. A positive DEF suggests that there is a need for external financing, 
while a negative DEF means that internal funds are sufficient. It should be noted that the model is estimated over both positive and negative financing deficits, assuming a homogeneous and symmetric pecking order coefficient. Put differently, the simple pecking order suggests that the firm only issues or repurchases equity as a last resort. For firms with negative $D E F_{i t}$, it is also expected that $a=0$ and $b_{P O}=1$. However, the validity of the assumption of a homogeneous and symmetric pecking order coefficient in the SSM empirical model is questionable, which will be further discussed in section 3.1.

However, Shyam-Sunder and Myers’s (1999) empirical findings are not supported by a subsequent study by Frank and Goyal (2003) based on a much larger sample. Frank and Goyal (2003) report a puzzling result that large firms are more likely to follow pecking order behaviour. This result is inconsistent with the standard pecking order theory based on information asymmetry, since firm size is perceived to be negatively related to information asymmetry problem. ${ }^{8}$ This puzzling result is referred to pecking order puzzle or size anomaly (De Jong et al., 2010). However, as pointed out by Malmendier, Tate and Yan (2011), this puzzle may be explained by managerial overconfidence. Specifically, managers of those large firms become overconfident due to good past performance and thus have a more pronounced pecking order preference. An alternative explanation might be that overconfident managers in small firms have a reverse pecking order preference. One major motivation of this study is to see whether managerial overconfidence can help explain the pecking order puzzle.

It has been recognized that pecking order theory is a conditional theory. ${ }^{9}$ Its performance thus largely depends on various underlying assumptions. Using modified SSM regressions, where the pecking order coefficient is treated as heterogeneous, a growing body of literature

\footnotetext{
${ }^{8}$ The literature (e.g., Frank and Goyal, 2003; Low and Chen, 2004; Bharah et al., 2009; Brick and Liao, 2017) often considers information aysmmetry as a key condition of the pecking order preference.

${ }^{9}$ A good description of conditional theory is as follows: “... the theory finds support when its basic assumptions hold in the data, as should reasonably be expected of any theory” (Bharath et al., 2009).
} 
examines various conditions (e.g. information asymmetry, mispricing and market conditions). Bharath et al. (2009) examine the impact of information asymmetry on the pecking order preference by looking at the interaction between information asymmetry and the DEF. They find that firms with higher information asymmetry are more likely to exhibit pecking order behaviour. Elliott et al. (2007) test the impact of equity mispricing on the pecking order preference. They interact an equity valuation-based measure of firm mispricing with the DEF. They find that equity overvaluation weakens the preference for debt over equity financing. Huang and Ritter (2009) investigate the impact of market-level mispricing on the pecking order preference by interacting the implied market-level equity risk premium (ERP) with the DEF. They find that the ERP is positively associated with the preference for debt over equity financing, that is, a positive coefficient on the interaction between the ERP and the DEF. Notably, Huang and Ritter’s (2009) empirical analysis only focuses on firm-years with financing deficits (i.e. positive DEF) but not financing surplus (i.e. negative DEF). Our empirical analysis also distinguishes between firm-years with financing deficits and surplus. In the subsequent section, we discuss the effects of managerial overconfidence on the pecking order preference.

\subsection{Hypothesis development}

This section develops two competing hypotheses based on behavioural theories of capital structure which suggest that managerial overconfidence can either enhance or weaken pecking order preference. It has been recognized that the existing empirical evidence on pecking order preference can be almost, at face value, explained by managerial optimism (Baker and Wurgler, 2013). However, the theoretical relation between managerial overconfidence and pecking order behaviour is sensitive to the modelling framework. Heaton's (2002) model shows that optimistic managers prefer debt to equity since the latter is perceived to be 
undervalued. Malmendier and Tate (2005) argue that Heaton’s (2002) model provides a reinterpretation of the information asymmetry-based pecking order model by Myers-Maljuf (1984). The idea is that managerial optimism is associated with perceived positive information. In a similar vein, Malmendier, Tate and Yan (2011) develop a model ${ }^{10}$ of overconfidence and financing decisions. Their model predicts that overconfident managers only use external finance if overestimated returns to investment are greater than the perceived costs of external financing. However, when they do use external financing, overconfident managers, who believe that debt is less subject to mispricing relative to equity, tend to use more debt than their rational counterparts. In brief, their main prediction regarding the pecking order behaviour is also consistent with Heaton (2002) and can be stated as follow.

Hypothesis 1a: Managerial overconfidence can enhance the preference for debt over equity financing.

In contrast to the predictions of Heaton (2002) and Malmendier, Tate and Yan (2011), Hackbarth's (2008) model shows that managerial overconfidence may lead to a reverse pecking order preference. This proposition is inconsistent with Heaton’s (2002) model, which can be attributed to the different modelling approaches of managerial overconfidence. In particular, in Hackbarth's (2008) model, overconfidence is modelled as risk perception bias (i.e. underestimation of the riskiness of earnings) which makes overconfident managers believe that debt is undervalued by the market because their perceived default risk is lower. In

\footnotetext{
10 Their model allows for two frictions including tax benefit of debt and financial distress cost. Overconfidence is defined as "the overestimation of mean returns to investment". Managerial overconfidence can lead to either overinvestment or underinvestment, depending on the availability of internal funds or riskless debt financing. In particular, overconfident managers with sufficient internal or riskless financing are prone to overinvest. Another implication of overconfidence is that overconfident manager may have a biased perception of the cost of external financing. For this reason, if there is financing deficit, overconfident managers may underinvest.
} 
contrast, overconfident managers who underestimate the riskiness of earnings believe that their firms' equity is overvalued because of the convexity of equity. Put differently, equity can be viewed as a call option ${ }^{11}$ on firm's assets and the value of this call option is partly determined by the risks of firm's project. Given that the value of call option is positively related to project risk ${ }^{12}$, overconfident managers who underestimate the project risk believe that equity is overvalued. Hackbarth's (2008) model therefore suggests that overconfident managers with risk perception bias believe that debt is undervalued but equity is overvalued and hence have a reverse pecking order preference. The reversal of the pecking order is in the sense that overconfident managers rely more on equity than debt to finance deficits. Based on Hackbarth (2008), we propose the following hypothesis.

Hypothesis 1b: Managerial overconfidence can weaken the preference for debt over equity financing.

\section{Methodology and data}

\subsection{The empirical model}

To test the effect of managerial overconfidence on the pecking order preference for debt over equity financing, we adopt the modified Shyam-Sunder and Myers (SSM) (1999) regression framework where the pecking order coefficient (i.e. the coefficient on the financing deficit (DEF)) is heterogeneous and asymmetric. This section briefly describes these two important

\footnotetext{
${ }^{11}$ Shareholders have a call option on the firm with an exercise price of $X$. In a call-option graph where the horizontal axis is cash flow to firm and vertical axis is cash flow to shareholders, if firm's cash flow is beyond $X$, shareholders will exercise the option by buying the firm from the debt holders for the price $X$. If firm's cash flow is below $X$, shareholders will not exercise the call option and debt holders receive entire firm's cash flow.

${ }^{12}$ As shown in Black-Scholes model, the value of call option is positively related to the variance of the continuous stock returns.
} 
dimensions of our empirical model, namely heterogeneity and asymmetry of the pecking order coefficient.

The original SSM (1999) test assumes that the pecking order coefficient is homogeneous. However, there might be cross-sectional differences in terms of the degree of the pecking order preference. As discussed earlier, the empirical performance of the pecking order theory depends on its underlying conditions (e.g., information asymmetry, managerial overconfidence). It is thus more appropriate to assume that the pecking order coefficient is heterogeneous. Empirically, one may interact the financing deficit (DEF) with potential conditions of the pecking order preference. For example, Malmendier, Tate and Yan (2011) adds an interaction term between managerial overconfidence and the DEF to the SSM (1999) regression to examine the effect of managerial overconfidence on the pecking order preference. However, their empirical model does not distinguish between firms with financing deficit and surplus, which is based on the questionable assumption that the pecking order coefficient is symmetric. In what follows, we discuss why it is more plausible to assume the pecking order coefficient in the SSM (1999) regression is asymmetric.

The original SSM (1999) test and many subsequent studies (e.g., Frank and Goyal, 2003; Sánchez-Vidal and Martín-Ugedo, 2005; Bharath et al., 2009) do not distinguish between negative and positive financing deficit (DEF). According to SSM (1999), pecking order behaviour is assumed to be symmetric, meaning that "the simple pecking order's predictions do not depend on the sign of DEF". Put differently, they believe that "the Myers-Majluf reasoning works in reverse when the company has a surplus and wants to return cash to investors”. However, Kayhan and Titman (2007) point out that SSM's (1999) approach fails to account for asymmetry between positive and negative DEF. They argue that this asymmetry exists because equity issuance and repurchase are associated with different information issues. To empirically capture this asymmetric effect, Kayhan and Titman (2007) 
interact the DEF with a dummy variable indicating the sign of the DEF (e.g. the dummy variable equals one if the DEF is positive and zero otherwise). De Jong et al. (2010) empirically examine the asymmetry between the effects of financing deficits and surpluses. They also suggest that a correct pecking order specification should differentiate between financing deficits (i.e. positive DEF) and financing surpluses (i.e. negative DEF). ${ }^{13}$.

\subsection{Measurement of financing deficit (DEF)}

Financing deficit (DEF) can be defined using either balance sheet data (e.g., Fama and French, 2005; Chang and Dasgupta; 2009) or cash flow data (e.g., Shyam-Sunder and Myers, 1999; Frank and Goyal, 2003). This study uses both balance sheet and cash flow data to construct the DEF. Specifically, following the balance sheet approach adopted by Chang and Dasgupta (2009) and Huang and Ritter (2009), net debt issues is calculated as the difference between the change in total assets and the change in book equity; net equity issues is calculated as the difference between the change in book equity and the change in retained earnings. The DEF is defined as the sum of net equity issues and net debt issues, which is therefore equivalent to the change in total assets minus the change in retained earnings. Alternatively, Frank and Goyal (2003) use detailed positions of cash flow items to construct the DEF and recode missing values to be zero. In particular, they construct the DEF as the sum of dividend payments, capital expenditure, net increases in working capital and the current proportion of long-term debt at start of period minus operating cash flows after interest and taxes. To avoid recoding, similar to Bessler, Drobetz and Grüninger (2011), we use aggregated cash flow items. Specifically, net debt issues is measured as long term borrowings minus reduction in

\footnotetext{
${ }^{13}$ They propose the following model to capture the asymmetric pecking order behaviour: $\Delta D_{i t}=\alpha+\beta_{1} d_{i t}+\beta_{p o} D E F_{i t}+\beta_{\text {sur }} d_{i t} * D E F_{i t}+\varepsilon_{i t}$, where, $d_{i t}$ is a dummy variable that equals one if $D E F_{i t}<0$, and zero otherwise. The pecking order coefficient is $\beta_{p o}$ and $\left(\beta_{p o}+\beta_{\text {sur }}\right)$ respectively for the firms with financing deficits and financing surpluses. They find that the estimated pecking order coefficient is $0.90,0.74$ and 0.09 respectively for financing surpluses, normal deficits and large deficits.
} 
long term debt. Net equity issues is measured as net proceeds from sale/issue of common and preferred stock ${ }^{14}$ minus common/preferred redeemed, retired and converted. The above variables are scaled by net assets (i.e. total assets minus current liabilities). ${ }^{15}$

\subsection{Measurement of managerial overconfidence}

We use one words-based measure and two action-based measures of managerial overconfidence. Words-based overconfidence measure is based on tone analysis of Chairman's Statement. Two action-based measures are overconfidence beliefs revealed from firm's investment activity and insider trading behaviour respectively. In addition, an R\&Dbased measure of overconfidence is used as a robustness test. Different from the static measures of overconfidence commonly employed in the literature, our overconfidence measures, especially the words-based measures, are time-varying ${ }^{16}$.

\subsubsection{Words-based measure of overconfidence: optimistic tone}

We construct two composite tone indices. One is based on the raw tone measures. The other is orthogonalized so that each component is not correlated with certain firm characteristics (especially standard capital structure determinants). Our first measure of managerial overconfidence is based on tone analysis ${ }^{17}$ of Chairman's Statement. We construct optimistic tone measures by counting both optimism-increasing and optimism-decreasing words. We use

\footnotetext{
${ }^{14}$ This can also be calculated as the sum of proceeds from stock options and other proceeds from sale/issue of common/preferred stock.

${ }^{15}$ See Appendix A in Bessler et al. (2011) for a detailed discussion on the calculation of the DEF. Bessler et al. (2011) also use Worldscope data for their international study.

${ }^{16}$ Existing behavioural finance studies (e.g., Malmendier and Tate, 2005; Malmendier, Tate and Yan, 2011) tend to model managerial overconfidence as a habitual behaviour which is static. This static approach can be problematic because other behavioural biases, especially self-attribution bias, may affect the confidence level.

${ }^{17}$ Tone analysis (and more generally textual analysis) is becoming increasingly popular in recent accounting and finance studies. For example, Rogers, Buskirk and Zechman (2011) examine the relation between disclosure tone and shareholder litigation. For a review on studies of corporate disclosures, please see Li (2010a).
} 
six individual wordlists. Our first three wordlists are the same as those in Rogers, Buskirk and Zechman (2011) and Davis, Ge, Matsumoto and Zhang (2015), namely OPTIMISM, TONE_H and TONE_LM. OPTIMISM is a measure of net optimism ${ }^{18}$ counted using a dictionary in Diction 6. ${ }^{19}$ TONE_H and TONE_LM are two wordlists developed by Henry (2008) and Loughran and McDonald (2011) respectively to measure positive and negative words especially in a financial context. TONE_H and TONE_LM are calculated as the ratio of the difference between positive and negative words to the sum of positive and negative words. ${ }^{20}$ Besides, we also use another three tone measures, all of which are positively related to optimism, including CERTAIN1, CERTAIN2 and EMOTION. CERTAIN1 and EMOTION ${ }^{21}$ are measured using dictionaries in Linguistic Inquiry and Word Count (LIWC) 2007. CERTAIN2 is another measure of certaint $\mathrm{y}^{22}$ based on a dictionary in Diction 6. Similarly, Li (2010b) includes "uncertain tone", which is highly associated with negative tone, in his tone measure.

Next, we form a composite tone index using principal component analysis (PCA). In particular, we define $T O N E_{i t}$ as the first principal components of the correlation matrix of six raw tone measures. The first component, with an eigenvalue of $2.609,{ }^{23}$ explains 43.5 percent of our sample variance.

\footnotetext{
${ }^{18}$ In Diction, optimism is defined as "language endorsing some person, group, concept or event, or highlighting their positive entailments”.

19 As a unique feature of Diction software, there is standardization procedure when calculating a particular item. In particular, we compare our collected Chairman's Statements to three alternative norms in Diction including (1) all cases, (2) corporate financial reports and (3) corporate public relations. Our empirical results are qualitatively similar using alternative norms.

${ }^{20}$ The terms "positive/negative" and "optimistic/pessimistic" are often used interchangeably in the literature (e.g., Davis, Piger and Sedor, 2012). Li (2010b) standardize the terms to "positive/negative" instead of "optimistic/pessimistic".

${ }^{21}$ An earlier version of LIWC has a category named "optimism”, however in the 2007 version words are classified more broadly into "positive emotion" and "negative emotion".

${ }^{22}$ In Diction, certainty is defined as "language indicating resoluteness, inflexibility, and completeness and a tendency to speak ex cathedra”.

${ }^{23}$ The eigenvalue of second component is close to one (i.e. 1.135).
} 


$$
\begin{aligned}
& \text { TONE }_{i t}=\sum_{j=1}^{6} \text { Loading }_{i j} * \text { Tone_X }_{i j t} \\
& =0.496 \text { Emotion }_{i t}+0.192 \text { Certain }_{i t}+0.4460 \text { ptimism }_{i t} \\
& +0.027 \text { Certain } 2_{i t}+0.480 \text { Tone_H } H_{i t}+0.536 \text { Tone_LM } M_{i t}
\end{aligned}
$$

where, Tone_X $X_{i j t}$ represent individual tone measure $j$ of firm $i$ in fiscal year $t$. Loading $_{i j}$ is the loading for individual tone measure $j$ of firm $i$. The loading for Certain1 and Certain2 is much lower compared with other tone measures. However, our empirical results are qualitatively similar when we exclude those two measures of certainty tone.

To address the concern that the raw tone might be contaminated by firm-specific variables $^{24}$, a composite index of the orthogonalized tone measures is constructed as follows. First, we regress each individual tone measure on standard determinants of capital structure as follows:

$$
\text { Tone_X } X_{i j t}=\alpha+\beta_{1} \text { Profit }_{i t}+\beta_{2} M B_{i t}+\beta_{3} \text { Size }_{i t}+\beta_{4} \text { Tangibility }_{i t}+\varepsilon_{i j t}
$$

where, Tone_X $X_{i j t}$ represents six individual tone measures. $\varepsilon_{i j t}$ is the corresponding orthogonalized individual tone measures. Next, an orthogonalized composite index ( TONE_RES $E_{i t}$ ) is formed based on the first principal component of six residuals (i.e.

\footnotetext{
${ }^{24}$ In terms of the determinants of tone (e.g., current performance, growth opportunities, operating risks and complexity), Huang, Teoh and Zhang (2013) find that tone, as measured using Loughran and McDonald (2011) wordlist, is positively related to market-to-book and volatility of stock returns and negatively related to firm size, age and number of business segments. Our orthogonalized tone measure (TONE_RES) controls for four standard determinants of capital structure (i.e. market-to-book, size, tangibility and profitability). The results are similar when we further control for stock price performance and firm age in equation 2.
} 
Tone $X_{i j t}^{\perp}=\varepsilon_{i j t}$ ) from the above regressions. The first component explains 41.8 percent of the sample variance ${ }^{25}$.

$$
\begin{aligned}
\text { TONE_RES } & =\sum_{j=1}^{6} \text { Loading }_{i j} * \text { Tone }_{X_{i j t}}^{\perp}=\sum_{j=1}^{6} \text { Loading }_{i j} * \varepsilon_{i j t} \\
& =0.495 \text { Emotion }_{i t}^{\perp}+0.154 \text { Certain } 1_{i t}^{\perp}+0.440 \text { Optimism } \\
\text { it } & +0.036 \text { Certain } 2_{i t}^{\perp}+0.490 \text { Tone }_{-} H_{i t}^{\perp}+0.545 \text { Tone_LM } M_{i t}^{\perp}
\end{aligned}
$$

We use Chairman's Statement in the UK annual report as the source of narrative for tone analysis for several reasons. First, Chairman's Statement is widely read by investors and analysts (Bartlett and Chandler, 1997), and is "the longest established” (Clatworthy and Jones, 2003). ${ }^{26}$ Second, Chairman's Statement is largely unaudited and not heavily regulated. The language used in Chairman's Statement is much less standard than Directors’ Report which is subject to regulatory requirements. Third, disclosure-related litigation is rare in the UK relative to the US. Therefore, the UK accounting narratives (e.g. Chairman's Statement) are relatively less constrained compared with the MD\&A in the US 10-K report. Finally, while Chairman's Statement is signed by chairman, who is often a non-executive director in the UK, existing literature ${ }^{27}$ seems to agree that Chairman's Statement is an organizational rather than

\footnotetext{
${ }^{25}$ The eigenvalues of first and second components are 2.509 and 1.139 respectively.

${ }^{26}$ Many previous studies on UK accounting narratives focus on Chairman's Statement (see e.g., Smith and Taffler, 2000, Clatworthy and Jones, 2003; Clatworthy and Jones, 2006). Smith and Taffler (2000) use Chairman's Statement to predict firm bankruptcy. Schleicher and Walker (2010) conduct manual content analysis of the tone of forward-looking statements (i.e. outlook sections) in the UK annual report (most of which are located at the end of Chairman's Statement).

${ }^{27}$ For example, Clatworthy and Jones (2003) argue that accounting narratives such as UK Chairman's Statement allow "management” to describe corporate financial performance. In addition, Schleicher and Walker (2010) attribute the bias in the tone of outlook statements to "managers". In particular, they argue that "managers with a willingness to engage in impression management are likely to target forward-looking statements", while 73.5 percent of the forward-looking narratives are located in Chairman's Statement (Schleicher and Walker, 2010).
} 
individual communication. This means that firm’s key financial decision makers (e.g. CEO and CFO) also have some influences on the choice of language in the Chairman's Statement.

\subsubsection{Action-based measure of overconfidence: overinvestment}

Our first action-based measure of overconfidence is industry-adjusted investment rate (IAIR). The idea is that overconfidence managers tend to overestimate the present value of future investment, which in turn leads to overinvestment. Therefore, higher IAIR may indicate that the manager of a particular firm is overconfident. Similarly, Campbell et al. (2011) and Huang-Meier et al. (2016) also use an investment-based measure of managerial overconfidence. More specifically, we construct the IAIR as the difference between a firm's investment rate and the median investment rate of the firms in the same Datastream's Level 4 (INDM4) industry as: $I A I R_{i t}=I R_{i t}-\overline{I R_{s, l t}}$, where, $I R_{i t}$ is the investment rate of firm $i$. $\overline{I R_{S, l t}}$ is the average investment rate of industry $s$. The investment rate is defined as the ratio of capital expenditures to beginning of year property, plant and equipment. Campbell, et al. (2010) classify CEOs as overconfident if their firm is in the top quintile of firms based on industry-adjusted investment rates for two consecutive years. However, we believe that managerial overconfidence is time-varying and therefore we create a dummy variable (IAIR_D) that takes the value of one if the IAIR is in the top quintile in a particular fiscal year and zero otherwise.

\subsubsection{Action-based measure of overconfidence: net purchase ratio}

We also gauge overconfidence based on how managers trade their own firms' shares. The insider trading patterns of the managers may reflect their perceptions of firms' prospects (Jenter, 2005). Overconfident managers tend to overestimate the future firm stock performance and underestimate risk, and hence are more willing to purchase their own stocks. 
In the spirit of Jenter (2005) and Jin and Kothari (2008), we use insider trading-based measure of managerial overconfidence. We construct the valued-based net purchase ratio (NPR) using the value of open market purchases and sales respectively as: $N P R_{i t}=\frac{B u y_{i t}-\operatorname{Sell}_{i t}}{B u y_{i t}+\text { Sell }_{i t}}$, where, $N P R_{i t}$ is the NPRs of CEO or CFO of firm $i$ in fiscal year $t$. Buy $i t$ is the aggregate value of insider purchases and $S e l l_{i t}$ is the aggregate value of insider sales. The NPR ranges from -1 to 1 and higher NPR indicates higher managerial overconfidence.

\subsection{The sample}

The data is from the following sources. The UK firms' financial data is obtained from Thomson Worldscope. Insider trading data is from Hemmington Scott. Chairman's Statements are manually collected from the company annual reports which are downloaded either through Northcote website or directly from company websites. Our sample of unbalanced panel data is constructed as follows. The selection of sample period is guided by data availability. All financial and utility firms are excluded. Firm observations with missing financial data are excluded. Observations with the length of fiscal period less than 11 months or over 13 months are excluded. To conduct tone analysis, we need the digital version of the UK company annual reports, so that the Chairman Statement can be readable by the content analysis software (i.e. LIWC 2007 and Diction 6) ${ }^{28}$. In addition, to construct the insider trading-based measure of overconfidence, only those firms with insider transactions in any year during our sample period are selected. All variables are winsorized at the $1^{\text {st }}$ and $99^{\text {th }}$ percentile to

\footnotetext{
${ }^{28}$ In terms of the procedure of content analysis, we first extract Chairman's Statements from annual report. Next, we detect transformation errors in the combined text file using the Spelling \& Grammar function in Microsoft Word 2010. Finally, various types of errors are manually corrected before the texts are inputted in the content analysis software.
} 
eliminate the effect of outliers. The final sample comprises 459 firms and 2283 observations during the period $1994-2011^{29}$.

\subsubsection{Descriptive statistics and correlation analysis}

Panel A in Table 1 provides descriptive statistics of main variables. The mean of $D E F \_C F$ is 0.080 , which is the sum of $\Delta D_{-} C F(0.020)$ and $\Delta E_{-} C F(0.060)$. The mean of $D E F \_B S$ is 0.190 , and the means of $\Delta D_{-} B S$ and $\Delta E_{-} B S$ are 0.120 and 0.070 respectively. Importantly, we find that the percentage of firm-years with negative DEF should not be neglected. Using aggregate cash flow data, the percentage of observations with negative DEF is $37.3^{30}$, while 8.9 and 53.8 percent of the observations have zero and positive DEF respectively. Similarly, using balance sheet data, around 39 percent of the observations have negative DEF. The large amount of observations with financing surplus makes it important to empirically investigate whether the magnitude of the pecking order coefficient in SSM framework will depend on the sign of DEF. The mean of firm size is 12.320 with a standard deviation of 2.240 . The majority of our sample firms seem not to have extremely high leverage (the maximum book and market leverages are 0.610 and 0.520 respectively), and thus their financing decisions are more likely to be motivated by pecking order preference ${ }^{31}$. Panel $\mathrm{B}$ in Table 1 shows the pairwise Pearson correlation matrix. The industry-adjusted investment rate dummy (IAIR_D) is positively correlated with both tone-based overconfidence measures (except TONE_D) and insider trading-based overconfidence measures. In unreported results, we compare balance sheet approach and cash flow approach by looking at the correlations between net debt issues,

\footnotetext{
${ }^{29}$ Most of the observations are after 2000 because machine readable annual reports are almost not available in the 1990s.

30 This is consistent with 36.2 percent in Lin et al.’s (2008) Taiwan firm sample.

31 Take debt capacity into consideration, the financing decisions of firms with "low to moderate" leverage are more likely to follow pecking order behaviour, while dynamic tradeoff theory becomes the primary explanation for the financing behaviour of firms with "high" leverage (and consequently high financial distress costs) (Lemmon and Zender, 2010).
} 
net equity issues and financing deficit (i.e. the sum of net debt and equity issues). The correlation between $\Delta D \_B S / N A\left(\Delta E \_B S / N A\right)$ and $\Delta D \_C F / N A\left(\Delta E \_C F / N A\right)$ is 0.605 (0.773). The correlation between DEF_BS/NA and DEF_CF/NA is 0.746 .

[Insert Table 1 here]

\section{Results and discussion}

To examine the effect of managerial overconfidence on the pecking order preference, we use a modified Shyam-Sunder and Myers (1999) financing deficit regression framework as follows:

$$
\Delta D_{i t}=a+\beta_{1} D E F_{i t}+\beta_{2} M O_{i t}+\beta_{3} M O_{i t} * D E F_{i t}+B_{4} \Delta \boldsymbol{X}_{i t}+v_{i}+e_{i t}
$$

where, $\Delta D_{i t}$ is net debt issues as a percentage of beginning-of-year net assets. $D E F_{i t}$ is a measure of financing deficit scaled by net assets. $M O_{i t}$ is managerial overconfidence. We use both words-based (i.e. optimistic tone) and action-based (i.e. firm investment and insider trading) measures of managerial overconfidence. $e_{i t}$ is the error term. $\Delta \boldsymbol{X}_{i t}$ is a vector of firmlevel controls including changes in market-to-book ratio, firm size, tangibility and profitability (see Frank and Goyal, 2003). Standard errors are adjusted for clustering at the firm level. $v_{i}$ is time-invariant firm-specific effects. $e_{i t}$ is the error term. ${ }^{32}$

In equation 4 , a key parameter of interest is $\beta_{3}$. If $\beta_{3}$ is positive, this indicates an increase in pecking order coefficient and an enhanced pecking order preference. If $\beta_{3}$ is negative, it indicates a decrease in pecking order coefficient and a weakened pecking order preference. More specifically, $\beta_{3}$ measures the fraction by which an overconfident manager

\footnotetext{
${ }^{32}$ Another way to test the impact of managerial overconfidence on the preference for debt over equity financing is logistic analysis which examines the probability of debt issues relative to equity issues. However, this approach fails to control for firm fixed effects.
} 
uses more (or less) debt financing to cover deficits. For instance, if $\beta_{3}$ is -0.1 , an overconfident manager uses 10 percentage points less debt to cover deficits. The other important area of interest is that the sum of the $\beta_{1}$ and $\beta_{3}$ gives us the overall proportion of debt used by overconfident managers to cover deficits. If the sum of $\beta_{1}$ and $\beta_{3}$ is less than 0.5 then it can be inferred that there is a reverse pecking order preference in the sense that less debt (below 50\%) than equity is being used to cover the deficit.

\subsection{Optimistic tone and pecking order preference}

Table 2 reports the effects of optimistic tone on pecking order coefficient (i.e. the coefficient on $D E F)$ in the Shyam-Sunder and Myers (1999) financing deficit regression. TONE_D and TONE_RES_D are binary variables that take the value of 1 if TONE and TONE_RES are above their sample median and 0 otherwise. In Table 2 Panel A, we calculate financing deficit and net debt issues using balance sheet data. We find that both TONE_D and TONE_RES_D have negative and statistically significant effects on the pecking order coefficient in models 14. The negative effect of these two tone dummies is economically and statistically stronger in models 3-4 which are based on the subsample of firms with financing deficit (i.e. $D E F>0$ ). The negative coefficients on TONE_D*DEF and TONE_RES_D*DEF suggest that managerial overconfidence, as measured by optimistic tone, leads to a significantly weakened pecking order preference. In contrast, in models 5-6 which are based on the subsample of firms with financing surplus (i.e. $D E F<0$ ), the tone dummies have positive and statistically insignificant impacts on the pecking order coefficient.

In Table 2 Panel B, we also examine the effects of tone on pecking order preference. As a robustness check, we calculate financing deficit and net debt issues using cash flow data. Consistent with the results in Panel A, we find that optimistic tone significantly weakens or reverses the pecking order preference especially for a subsample of firms with financing 
deficit. The above results suggest that tone leads to a significantly weakened or reverse pecking order preference. One major concern related to this words-based managerial overconfidence measure is that tone might be contaminated by information asymmetry, in which case rational managers use optimistic tone intentionally to reduce information asymmetry. However, if this is the case, tone that is contaminated by information asymmetry will enhance pecking order preference, which is not consistent with our empirical findings. Therefore, it seems unlikely that the negative relation between tone and pecking order coefficient is driven by information asymmetry.

[Insert Table 2 here]

\subsection{Industry-adjusted investment rate and pecking order preference}

Table 3 reports the effects of an action-based managerial overconfidence measure, namely industry-adjusted investment rate dummy (IAIR_D), on pecking order preference. We find that $I A I R \_D$ has a negative and statistically significant effect on the pecking order coefficient in model 1 and 3 of both Panel A and B in Table 3. This finding suggests that managerial overconfidence, as measured by firms' overinvestment, leads to a reverse pecking order preference especially for firms with financing deficit (i.e. $D E F>0$ ). In addition, we construct an orthogonalized investment-based measure of overconfidence, namely IAIR_RES_D, defined as a dummy variable that takes the value of one if the orthogonalized industryadjusted investment rate (IAIR) is in the top quintile in a particular fiscal year and zero otherwise. This variable is orthogonal to a wide range of firm characteristics and proxies for investment opportunities including firm size, MB, profitability, tangibility, firm age, $R \& D$, dividend dummy, leverage, cash ratio, and price performance. ${ }^{33}$ Our empirical results are robust to this orthogonalized investment-based measure. In particular, we find that the

\footnotetext{
${ }^{33}$ We thank an anonymous referee for suggesting we use this orthogonalized investmentbased measure of overconfidence.
} 
coefficients on the interaction between IAIR_RES_D and DEF are negative and statistically significant in model 4 of Panel A and model 2 and 4 of Panel B in Table 3.

These results based on an action-based overconfidence measure further confirms our findings that optimistic tone is related to a significantly weakened or reverse preference for debt over equity financing. To sum up, we find that both managerial words-based measures (i.e. optimistic tone) and action-based measures (i.e. industry-adjusted investment rate) of managerial overconfidence leads to a significantly weakened or reverse preference for debt over equity especially when there is financing deficit. These findings are consistent with hypothesis $1 b$.

\section{[Insert Table 3 here]}

\subsection{Alternative specification: leverage regression}

Previous studies on the pecking order preference (Frank and Goyal, 2003; Bharath et al., 2009) emphasize the importance of employing alternative empirical strategies rather than relying on the SSM test. This is because the use of SSM framework to test pecking order theory is subject to criticism (Chirinko and Singha, 2000). To address this concern, we use an alternative specification, a standard leverage regression, where the dependent variable in the SSM regression is replaced with leverage as follows:

$$
L E V_{i t}=a+\beta_{1} D E F_{i t}+\beta_{2} M O_{i t}+\beta_{3} M O_{i t} * D E F_{i t}+B_{4} \Delta \boldsymbol{X}_{i t}+v_{i}+e_{i t}
$$

where, $L E V_{i t}$ is book leverage. Other variables are the same as those in equation 4.

Table 4 examines the effects of optimistic tone dummies (i.e. TONE_D and $T O N E \_R E S \_D$ ) and industry-adjusted investment rate dummies (i.e. IAIR_D and $I A I R \_R E S \_D$ ) on the relationship between financing deficit (DEF) and leverage. Hypothesis 
$1 b$ predicts that managerial overconfidence weakens the positive relationship between the DEF and leverage. Consistent with this prediction, the coefficients on the interaction between TONE_D and DEF are negative and statistically significant in model 1 and 3 in Panel A. In addition, the coefficients on the interaction between both tone dummies, TONE_D and TONE_RES_D, and DEF are negative and statistically significant in model 1-4 in Panel B. In Panel C and D, we find further supporting evidence based on the action-based managerial overconfidence measures, IAIR_D and IAIR_RES_D. In brief, the above evidence is consistent with hypothesis $1 b$, and suggests that managerial overconfidence is associated with a preference for equity over debt financing.

\section{[Insert Table 4 here]}

\subsection{Further analysis}

4.4.1. What is the underlying channel through which managerial overconfidence leads to a reverse pecking order preference?

Recall hypothesis $1 b$ that overconfident managers with risk perception bias who underestimate the riskiness of firm earnings have a reverse pecking order preference. If risk perception bias is the channel through which managerial overconfidence weakens pecking order preference, we expect the overconfidence-induced reverse pecking order preference is more pronounced especially for firms with higher earnings volatility. Consistent with this conjecture, we find that, for firms with relatively higher earnings volatility, both optimistic tone and industry-adjusted investment rate have negative and significant impacts on the pecking order preference (see model 3 in Panel A and models 1-2 in Panel B of Table 5). In contrast, for firms with low earnings volatility, the impacts of tone and industry-adjusted investment rate on the pecking order preference are of weak magnitude and statistically insignificant. 
We may therefore conclude that managerial overconfidence has negative and statistically significant impacts on the pecking order preference only for those firms with relatively higher earnings volatility. This is consistent with overconfident managers in those highly volatile (in terms of the earnings) firms having a biased perception of the riskiness of earnings. This biased perception of earnings volatility in turn leads to a much weaker pecking order preference as we described in hypothesis $1 b$. In brief, the above subsample analysis based on firm earnings volatility further confirms hypothesis $1 b$ by suggesting that the overconfidenceinduced weakening of pecking order preference is clearly connected to the underestimation of earnings volatility.

[Insert Table 5 here]

\subsubsection{Can managerial overconfidence explain the pecking order puzzle (size anomaly)?}

Next, we examine whether the effects of managerial overconfidence on pecking order preference are different for small and large firms. This analysis is motivated by the pecking order puzzle documented by Frank and Goyal (2003) that firm size is positively associated with the degree of pecking order preference, which contradicts the standard pecking order theory. A potential explanation for this puzzle is that overconfident managers in smaller firms are reluctant to follow standard pecking order although smaller firms are subject to higher information costs. To test this conjecture, we split the whole sample into two subsamples based on firm size: models 1-4 in Panel A and models 1-2 in Panel B of Table 6 includes firm-year observations with firm size below median, while models 5-8 in Panel A and models 3-4 in Panel B of Table 6 includes firm-year observations with firm size above median.

Table 6 compares the effects of our overconfidence measures, optimistic tone (see Panel A) and industry-adjusted investment rate (see Panel B) respectively, on pecking order preference for small and large firms. Consistent with Frank and Goyal's (2003) observation 
that small firms exhibit weaker pecking order preference, we also find that the pecking order coefficient (i.e. the coefficient on $D E F$ ) is smaller for small firms. More importantly, we find that both optimistic tone (see models 1, 2 and 5 in Panel A of Table 6) and industry-adjusted investment rate (see model 2 in Panel B of Table 6) have negative and statistically significant impacts on the pecking order coefficient especially for small firms. This finding sheds important light on the pecking order puzzle. In particular, our results suggest that managerial overconfidence in small firms makes those small firms less willing to follow standard pecking order and therefore contribute to the pecking order puzzle (or size anomaly).

[Insert Table 6 here]

4.4.3. Do net purchases (as a proxy for overconfidence) of CEO and CFO have the same impact on pecking order preference?

Table 7 presents the effects of overconfidence of both CEO and CFO, as measured by their net purchase ratio (NPR), on the pecking order preference. CEO_NPRD and CFO_NPRD are binary variables that take the value of 1 if the NPR of CEO and CFO respectively take the value of one and 0 otherwise. In Panel A, financing deficits and net debt issues are calculated using balance sheet data. We find that the coefficients on CFO_NPRD*DEF are negative and statistically significant (see models 2 and 4 in Panel A of Table 8). This finding suggests that the CFO net purchase leads to weakened pecking order preference. The results related to the CFO net purchase is consistent with our findings based on alternative overconfidence measures (i.e. optimistic tone and industry-adjusted investment rate) that managerial overconfidence weakens the pecking order preference. In contrast, the coefficients on CEO_NPRD*DEF are positive but statistically insignificant (see models 1 and 3 in Panel A of Table 7). The opposite effect of CEO net purchase could potentially be attributed to the fact that CEO has more private information about the firm relative to CFO and therefore CEO's 
trading is more likely to be driven by information asymmetry rather than CEO overconfidence. In other words, CEO insider trading more reflects private information rather than overconfidence. Therefore, we find that CEO net purchase, which is likely to be contaminated by information asymmetry, is associated with an enhanced pecking order preference.

In Panel B, we calculate financing deficit and net debt issues using cash flow data. The results in models 1-4 of Panel B are generally consistent with those in Panel A in terms of the signs of the coefficients on CEO_NPRD*DEF and CFO_NPRD*DEF but statistically insignificant. Overall, the evidence based on the insider trading-based measures of CEO and CFO overconfidence are relatively mixed and statistically weaker, which may be due to the fact that insider trading is likely to be driven by information asymmetry. However, the finding that CFO overconfidence as measured by their net purchase of their own firms' share leads to a weakened pecking order preference is consistent with our main findings based on our main measures of managerial overconfidence (i.e. optimistic tone and industry-adjusted investment rate).

[Insert Table 7 here]

\subsection{Alternative overconfidence measures and pecking order preference}

As a robustness check, we employ an alternative, albeit imperfect, investment-based measure of managerial overconfidence based on the R\&D intensity. Shefrin (2007, p. 4-6) provides a case study illustrating the link between managerial overconfidence and R\&D investment. Sun Microsystems increased R\&D investment in 2000, which in turn significantly decreased firm market value. This value-destroying $\mathrm{R} \& \mathrm{D}$ investment is attributed to the overconfidence bias of Sun's CEO, Scott McNealy, who is often described by the media as "optimistic” and holds firm stock options too long. In addition, previous studies (Galasso and Simcoe, 2011; 
Hirshleifer et al., 2012) provide strong evidence that highly intensive firm innovation activities can be significantly driven by managerial overconfidence.

We thus construct an R\&D-based managerial overconfidence measure, namely $R \& D \_D$, defined as a dummy variable that equals one if the R\&D-to-sales ratio of a firm is in the top quintile in a particular fiscal year and zero otherwise. In addition, we construct an orthogonalized R\&D-based overconfidence measure, namely $R \& D \_R E S \_D$, defined as a dummy variable that equals one if the orthogonalized R\&D-to-sales ratio is in the top quintile in a particular fiscal year and zero otherwise. This variable is orthogonal to firm size, MB, profitability, tangibility, firm age, dividend dummy, leverage, cash ratio, and price performance.

Table 8 shows that the coefficients on the interactions between the R\&D-based managerial overconfidence measures, $R \& D \_D$ and $R \& D \_R E S \_D$, and the DEF are negative and statistically significant in model 1-3 in Panel A and model 1-4 in Panel B. This additional evidence confirms our previous findings in Table 2 and 3, suggesting that our main findings are robust to alternative managerial overconfidence measures.

[Insert Table 8 here]

\subsection{Further robustness tests}

Our main findings are robust to three alternative model specifications. First, as an alternative way to test and compare the effects of managerial overconfidence on the pecking order coefficient of firms with positive and negative DEF, we use the following modified ShyamSunder and Myers (1999) regression:

$$
\begin{gathered}
\Delta D_{i t}=a+\beta_{1} P D E F_{i t}+\beta_{2} N D E F_{i t}+\beta_{3} M O_{i t}+\beta_{4} M O_{i t} * P D E F_{i t}+\beta_{5} M O_{i t} \\
* N D E F_{i t}+B_{6} \Delta X_{i t}+v_{i}+e_{i t}
\end{gathered}
$$


where, $\Delta D_{i t}$ is net debt issues as a percentage of beginning-of-year net assets. $P D E F_{i t}$ equals $D E F_{i t}$ if $D E F_{i t}>0$ and zero otherwise; $N D E F_{i t}$ equals $D E F_{i t}$ if $D E F_{i t}<0$ and zero otherwise. $M O_{i t}$ is managerial overconfidence. The definitions of other variables in this equation are the same as in equation 4. In this alternative specification, the pecking order coefficients are also heterogeneous and asymmetric. In untabulated results, we find that both tone dummies and IAIR_D have negative and significant effects on the coefficient of PDEF, which confirms our earlier finding that tone has negative and significant impacts on the coefficient of DEF especially in the subsample with positive DEF. In brief, two alternative specifications (i.e. equation 4 and 6) provide largely consistent results.

Second, we check whether our main findings are sensitive to scaling of the DEF. Although not required by the pecking order theory, the purpose of scaling is to control for the differences in firm size. Frank and Goyal (2003) point out that the coefficient estimates can be highly sensitive to scaling if the denominator is correlated with some variables in the regression. We therefore normalize the DEF by two alternative denominators, namely total assets and sales. The results are not sensitive to scaling. Third, as a robustness check, we exclude from our analysis those firm-years with zero leverage ${ }^{34}$. The reason is that standard capital structure theories (e.g. trade-off theory, pecking order theory and market timing theory) are almost silent on the zero-leverage puzzle that some firms do not use any debt financing. Given that the main purpose of this study is to test pecking order preference, we exclude zeroleverage observations from our tests and the empirical results are qualitatively similar.

Finally, our managerial overconfidence measures may be driven by investor sentiment. Specifically, managers may be more confident, especially when sentiment is high and firm's stocks are overvalued by the irrational investors. If this is the case, the relationship between

\footnotetext{
${ }^{34}$ Over 14 percent of the observations (i.e. 326 out of 2283 observations) have zero leverage in our sample.
} 
our overconfidence measures and the reverse pecking order behaviour may be partly attributed to investor sentiment, because the market timing theory of capital structure (Baker and Wurgler, 2002) suggests that managers tend to use more equity financing if they believe that their firms' stocks are overvalued in hot markets (Maung, 2014). To address this concern, in untabulated analysis we control for the UK Consumer Confidence Index ${ }^{35}$, as a proxy for investor sentiment. We construct several new orthogonalized overconfidence measures that are not correlated with investor sentiment, by controlling for investor sentiment in equation 2; however, we still find that the effects of these alternative overconfidence measures on the pecking order behaviour are consistent with our baseline results, ruling out the market timing explanation.

\section{Conclusions}

This paper is motivated by contrasting theoretical predictions made by Heaton (2002) and Hackbarth (2008) that managerial overconfidence can be either positively or negatively related to the degree of pecking order preference. A related study by Malmendier, Tate and Yan (2011) provides empirical evidence that CEO overconfidence leads to an enhanced pecking order preference. Our empirical strategies are different from Malmendier, Tate and Yan (2011) in two important aspects. First, we use modified Shyam-Sunder and Myers (1999) regression that distinguishes between firms with financing deficits and surpluses. Second, we extend prior work by developing and using time-varying measures of managerial overconfidence. Our empirical findings are in contrast to Malmendier, Tate and Yan (2011) but support Hackbarth’s (2008) proposition that managerial overconfidence can lead to a reverse pecking order preference. We find consistent evidence that managerial overconfidence

\footnotetext{
${ }^{35}$ The consumer confidence data can be downloaded from the European Commission website (https://ec.europa.eu/info/business-economy-euro/indicators-statistics/economic-databases), and has been used in previous studies (e.g., Schmeling, 2009) to measure investor sentiment.
} 
weakens the preference for debt over equity financing by a statistically significant and economically substantial amount. In many cases there is a reversal of pecking order preference in the sense that less debt then equity is used to finance deficits. This new evidence is consistent with Hackbarth's (2008) model prediction that overconfident managers with "risk perception bias" (i.e. underestimation of the riskiness of earnings) prefer equity over debt financing because of the convexity of equity.

Further support for this proposition is provided by showing that the overconfidenceinduced reverse pecking order preference is more pronounced for firms with high earnings volatility. This finding suggests that "risk perception bias" is the underlying channel through which overconfidence weakens the pecking order preference. Interestingly, we further document that managerial overconfidence is more strongly associated with a reverse pecking order preference especially for small firms. This finding sheds important light on the pecking order puzzle (or size anomaly): small firms surprisingly exhibit substantially weaker pecking order preference when their managers are overconfident. 
Table 1 Descriptive statistics and correlation matrix

Panel A presents the descriptive statistics of the main dependent and independent variables. Panel B shows Pearson correlation coefficients between all pairs of our main variables. All variables are defined in Appendix 1.

\begin{tabular}{|c|c|c|c|c|c|c|c|}
\hline \multicolumn{8}{|c|}{ Panel A. Descriptive statistics } \\
\hline Variable & Obs. & Mean & S.D. & Min. & Median & & Max. \\
\hline DEF_BS/NA & 2283 & 0.190 & 0.560 & -1.110 & 0.060 & & 3.040 \\
\hline$\triangle D \_B S / N A$ & 2283 & 0.120 & 0.370 & -0.630 & 0.040 & & 2.030 \\
\hline$\Delta E \_B S / N A$ & 2283 & 0.070 & 0.310 & -0.790 & 0.010 & & 1.950 \\
\hline$D E F \_C F / N A$ & 2283 & 0.080 & 0.330 & -0.430 & 0.000 & & 2.030 \\
\hline$\Delta D \_C F / N A$ & 2283 & 0.020 & 0.140 & -0.310 & 0.000 & & 0.790 \\
\hline$\Delta E \_C F / N A$ & 2283 & 0.060 & 0.260 & -0.310 & 0.000 & & 1.800 \\
\hline$M B$ & 2283 & 1.760 & 1.260 & 0.560 & 1.400 & & 8.790 \\
\hline Firm size & 2283 & 12.320 & 2.240 & 6.140 & 12.510 & & 16.870 \\
\hline Tangibility & 2283 & 0.260 & 0.230 & 0.000 & 0.200 & & 0.890 \\
\hline Profitability & 2283 & 0.090 & 0.180 & -0.880 & 0.120 & & 0.390 \\
\hline TONE & 2283 & -0.000 & 1.615 & -5.693 & 0.150 & & 3.676 \\
\hline TONE_D & 2283 & 0.500 & 0.500 & 0.000 & 1.000 & & 1.000 \\
\hline CEO_NPR & 1327 & 0.330 & 0.890 & -1.000 & 1.000 & & 1.000 \\
\hline CEO_NPRD & 1327 & 0.610 & 0.490 & 0.000 & 1.000 & & 1.000 \\
\hline CFO_NPR & 1071 & 0.460 & 0.830 & -1.000 & 1.000 & & 1.000 \\
\hline CFO_NPRD & 1071 & 0.680 & 0.470 & 0.000 & 1.000 & & 1.000 \\
\hline$I A I R \_D$ & 2283 & 0.100 & 0.300 & 0.000 & 0.000 & & 1.000 \\
\hline \multicolumn{8}{|c|}{ Panel B. Correlation matrix } \\
\hline & 1 & 2 & 3 & 4 & 5 & 6 & 7 \\
\hline 1. TONE & 1 & & & & & & \\
\hline 2. TONE_D & 0.796 & 1 & & & & & \\
\hline 3. CEO_NPR & -0.156 & -0.050 & 1 & & & & \\
\hline 4. CEO_NPRD & -0.147 & -0.053 & 0.936 & 1 & & & \\
\hline 5. CFO_NPR & -0.141 & -0.054 & 0.670 & 0.617 & 1 & & \\
\hline 6. CFO_NPRD & -0.116 & -0.031 & 0.609 & 0.595 & 0.933 & 1 & \\
\hline 7. IAIR_D & 0.004 & 0.020 & 0.036 & 0.055 & 0.050 & 0.059 & 1 \\
\hline
\end{tabular}




\section{Table 2 Optimistic tone and pecking order preference}

This table examines the effect of optimistic tone dummies (i.e. TONE_D and TONE_RES_D that are one if tone index and orthogonalized tone index are above their median respectively and zero otherwise) on the pecking order preference by looking at the interaction between tone dummies and financing deficit (DEF) in the ShyamSunder and Myers (1999) financing deficit regression framework. The dependent variable is net debt issues scaled by net assets. Financing deficit and net debt issues are calculated using balance sheet and cash flow data in Panel A and B respectively. Models 1-2 are based on the full sample, while models 3-4 and models 5-6 focus on firm-years observations with financing deficit (i.e. $D E F \_B S>0$ or $D E F \_C F>0$ ) and financing surplus (i.e. $D E F \_B S<0$ or $D E F \_C F<0$ ) respectively. Constants are included but not reported. All models are estimated using fixed effects within estimators. Robust standard errors are adjusted for firm-level clustering. P-values are given in parentheses. ${ }^{* *}, * *$ and $*$ indicate that coefficient is significant at $1 \%, 5 \%$ and $10 \%$ levels, respectively.

\begin{tabular}{|c|c|c|c|c|c|c|}
\hline \multicolumn{7}{|c|}{ Panel A. The interaction between tone and DEF_BS } \\
\hline \multicolumn{7}{|c|}{ Dependent variable: net debt issues scaled by net assets } \\
\hline & \multicolumn{2}{|c|}{ Full sample(models 1-2) } & \multicolumn{2}{|c|}{ DEF_BS>0 (models 3-4) } & \multicolumn{2}{|c|}{ DEF_BS $<0$ (models 5-6) } \\
\hline & $(1)$ & $(2)$ & (3) & $(4)$ & $(5)$ & $(6)$ \\
\hline \multirow[t]{2}{*}{$D E F$} & $0.603^{* * *}$ & $0.591 * * *$ & $0.643^{* * *}$ & $0.612 * * *$ & $0.240 * * *$ & $0.228 * * *$ \\
\hline & $(0.000)$ & $(0.000)$ & $(0.000)$ & $(0.000)$ & $(0.001)$ & $(0.002)$ \\
\hline \multirow[t]{2}{*}{ TONE_D } & 0.012 & & 0.018 & & 0.014 & \\
\hline & $(0.307)$ & & $(0.247)$ & & $(0.354)$ & \\
\hline \multirow[t]{2}{*}{$T O N E \_D * D E F$} & $-0.085^{* *}$ & & $-0.122 * * *$ & & 0.000 & \\
\hline & $(0.024)$ & & $(0.006)$ & & $(0.999)$ & \\
\hline \multirow[t]{2}{*}{ TONE_RES_D } & & $0.022^{*}$ & & 0.028 & & 0.022 \\
\hline & & $(0.062)$ & & $(0.126)$ & & $(0.115)$ \\
\hline \multirow[t]{2}{*}{$T O N E \_R E S \_D * D E F$} & & $-0.070 *$ & & $-0.087^{*}$ & & 0.025 \\
\hline & & $(0.099)$ & & $(0.098)$ & & $(0.782)$ \\
\hline \multirow[t]{2}{*}{$\Delta M B$} & -0.006 & -0.006 & 0.003 & 0.001 & -0.002 & -0.002 \\
\hline & $(0.555)$ & $(0.542)$ & $(0.821)$ & $(0.899)$ & $(0.866)$ & $(0.846)$ \\
\hline \multirow[t]{2}{*}{$\Delta$ Firm size } & $0.140 * * *$ & $0.143 * * *$ & $0.116^{* *}$ & $0.120 * *$ & $0.161^{* * *}$ & $0.163 * * *$ \\
\hline & $(0.000)$ & $(0.000)$ & $(0.013)$ & $(0.018)$ & $(0.004)$ & $(0.003)$ \\
\hline \multirow[t]{2}{*}{$\Delta$ Tangibility } & -0.026 & -0.010 & 0.271 & $0.277^{*}$ & -0.195 & -0.189 \\
\hline & $(0.826)$ & $(0.930)$ & $(0.103)$ & (0.099) & $(0.243)$ & $(0.254)$ \\
\hline \multirow[t]{2}{*}{$\Delta$ Profitability } & $-0.259 * * *$ & $-0.262 * * *$ & $-0.318 * * *$ & $-0.326 * * *$ & $-0.204 * * *$ & $-0.205^{* * *}$ \\
\hline & $(0.002)$ & $(0.003)$ & $(0.004)$ & $(0.005)$ & $(0.002)$ & $(0.002)$ \\
\hline Within $\mathrm{R}^{2}$ & 0.687 & 0.686 & 0.664 & 0.659 & 0.206 & 0.208 \\
\hline Obs. & 2283 & 2283 & 1451 & 1451 & 832 & 832 \\
\hline \multicolumn{7}{|c|}{ Panel B. The interaction between tone and DEF_CF } \\
\hline & \multicolumn{6}{|c|}{ Dependent variable: net debt issues scaled by net assets } \\
\hline & \multicolumn{2}{|c|}{ Full sample (models 1-2) } & \multicolumn{2}{|c|}{ DEF_CF $>0$ (models 3-4) } & \multicolumn{2}{|c|}{ DEF_CF $<0$ (models 5-6) } \\
\hline & $(1)$ & $(2)$ & (3) & (4) & $(5)$ & $(6)$ \\
\hline \multirow[t]{2}{*}{$D E F$} & $0.813^{* * *}$ & $0.748 * * *$ & $0.812 * * *$ & $0.709 * * *$ & $0.487 * *$ & 0.296 \\
\hline & $(0.000)$ & $(0.000)$ & $(0.000)$ & $(0.000)$ & $(0.011)$ & $(0.318)$ \\
\hline \multirow[t]{2}{*}{ TONE_D } & $0.043^{* * *}$ & & $0.075 * * *$ & & 0.021 & \\
\hline & $(0.006)$ & & $(0.009)$ & & $(0.334)$ & \\
\hline \multirow[t]{2}{*}{$T O N E \_D * D E F$} & $-0.234 * * *$ & & $-0.329 * * *$ & & -0.267 & \\
\hline & $(0.004)$ & & $(0.001)$ & & $(0.332)$ & \\
\hline TONE_RES_D & & $0.042 * * *$ & & $0.068 * *$ & & 0.044 \\
\hline & & $(0.006)$ & & $(0.011)$ & & $(0.103)$ \\
\hline$T O N E \_R E S \_D * D E F$ & & $-0.145^{*}$ & & $-0.191 *$ & & 0.088 \\
\hline & & $(0.087)$ & & $(0.072)$ & & $(0.770)$ \\
\hline$\Delta M B$ & $-0.036 * * *$ & $-0.034 * * *$ & $-0.032 * *$ & $-0.030^{*}$ & -0.029 & -0.024 \\
\hline & $(0.003)$ & $(0.005)$ & $(0.047)$ & $(0.063)$ & $(0.101)$ & $(0.161)$ \\
\hline$\Delta$ Firm size & $0.301 * * *$ & $0.311^{* * *}$ & $0.313^{* * *}$ & $0.331 * * *$ & $0.450 * * *$ & $0.457 * * *$ \\
\hline & $(0.000)$ & $(0.000)$ & $(0.000)$ & $(0.000)$ & $(0.004)$ & $(0.003)$ \\
\hline$\Delta$ Tangibility & -0.185 & -0.182 & -0.222 & -0.209 & 0.049 & 0.049 \\
\hline & $(0.322)$ & $(0.334)$ & $(0.386)$ & $(0.427)$ & $(0.880)$ & $(0.880)$ \\
\hline$\Delta$ Profitability & $-0.389 * * *$ & $-0.398 * * *$ & $-0.529 * * *$ & $-0.571 * * *$ & $-0.349 * * *$ & $-0.346 * * *$ \\
\hline & $(0.000)$ & $(0.000)$ & $(0.001)$ & $(0.000)$ & $(0.005)$ & $(0.005)$ \\
\hline Within $\mathrm{R}^{2}$ & 0.384 & 0.379 & 0.370 & 0.356 & 0.160 & 0.157 \\
\hline Obs. & 2283 & 2283 & 1124 & 1124 & 1067 & 1067 \\
\hline
\end{tabular}


Table 3 Industry-adjusted investment rate and pecking order preference

This table examines the effect of industry-adjusted investment rate dummies (i.e. IAIR_D and IAIR_RES_D) on the pecking order preference by looking at the interaction between these dummies and financing deficit (DEF) in the Shyam-Sunder and Myers (1999) financing deficit regression framework. The dependent variable is net debt issues scaled by net assets. Financing deficit and net debt issues are calculated using balance sheet and cash flow data in Panel A and B respectively. Models 1-2 are based on the full sample, while models 3-4 and models 5-6 focus on firm-years observations with financing deficit (i.e. $D E F \_B S>0$ or $D E F \_C F>0$ ) and financing surplus (i.e. $D E F \_B S<0$ or $D E F \_C F<0$ ) respectively. Constants are included but not reported. All models are estimated using fixed effects within estimators. Robust standard errors are adjusted for firm-level clustering. P-values are given in parentheses. $* * *, * *$ and * indicate that coefficient is significant at $1 \%, 5 \%$ and $10 \%$ levels, respectively.

\begin{tabular}{|c|c|c|c|c|c|c|}
\hline \multicolumn{7}{|c|}{ Panel A. The interaction between IAIR and DEF_BS } \\
\hline \multicolumn{7}{|c|}{ Dependent variable: net debt issues scaled by net assets } \\
\hline & \multicolumn{2}{|c|}{ Full sample (models 1-2) } & \multicolumn{2}{|c|}{ DEF_BS>0 (models 3-4) } & \multicolumn{2}{|c|}{ DEF_BS $<0$ (models 5-6) } \\
\hline & $(1)$ & $(2)$ & $(3)$ & $(4)$ & $(5)$ & $(6)$ \\
\hline \multirow[t]{2}{*}{ DEF } & $0.587 * * *$ & $0.564 * * *$ & $0.620 * * *$ & $0.594 * * *$ & $0.255^{* * *}$ & $0.260 * * *$ \\
\hline & $(0.000)$ & $(0.000)$ & $(0.000)$ & $(0.000)$ & $(0.000)$ & $(0.000)$ \\
\hline \multirow[t]{2}{*}{ IAIR_D } & $0.075 * * *$ & & $0.134 * * *$ & & $-0.127 * *$ & \\
\hline & $(0.002)$ & & $(0.000)$ & & $(0.029)$ & \\
\hline \multirow[t]{2}{*}{$I A I R \_D * D E F$} & $-0.152 * *$ & & $-0.219 * * *$ & & -0.242 & \\
\hline & $(0.020)$ & & $(0.005)$ & & $(0.210)$ & \\
\hline \multirow[t]{2}{*}{$I A I R \_R E S \_D$} & & 0.027 & & $0.060 * *$ & & $-0.079 * *$ \\
\hline & & $(0.149)$ & & $(0.038)$ & & $(0.022)$ \\
\hline \multirow[t]{2}{*}{$I A I R \_R E S \_D^{*} D E F$} & & -0.065 & & $-0.124 *$ & & -0.148 \\
\hline & & $(0.277)$ & & $(0.088)$ & & $(0.323)$ \\
\hline \multirow[t]{2}{*}{$\Delta M B$} & -0.005 & -0.005 & 0.000 & -0.000 & -0.003 & -0.002 \\
\hline & $(0.621)$ & $(0.580)$ & (0.989) & $(0.997)$ & $(0.813)$ & $(0.883)$ \\
\hline \multirow[t]{2}{*}{$\Delta$ Firm size } & $0.148 * * *$ & $0.150 * * *$ & $0.131 * *$ & $0.131 * *$ & $0.166^{* * *}$ & $0.171^{* * *}$ \\
\hline & $(0.000)$ & $(0.000)$ & $(0.011)$ & $(0.010)$ & $(0.003)$ & $(0.003)$ \\
\hline \multirow[t]{2}{*}{$\Delta$ Tangibility } & 0.028 & 0.002 & $0.393^{*}$ & $0.392 * *$ & -0.203 & -0.233 \\
\hline & $(0.828)$ & $(0.987)$ & $(0.056)$ & $(0.034)$ & $(0.226)$ & $(0.178)$ \\
\hline \multirow[t]{2}{*}{$\Delta$ Profitability } & $-0.241 * * *$ & $-0.258 * * *$ & $-0.295 * *$ & $-0.318 * * *$ & $-0.188 * * *$ & $-0.193 * * *$ \\
\hline & $(0.006)$ & $(0.003)$ & $(0.012)$ & $(0.007)$ & $(0.006)$ & $(0.005)$ \\
\hline Within $\mathrm{R}^{2}$ & 0.692 & 0.681 & 0.678 & 0.657 & 0.218 & 0.220 \\
\hline Obs. & 2283 & 2246 & 1451 & 1434 & 832 & 812 \\
\hline \multicolumn{7}{|c|}{ Panel B. The interaction between IAIR and DEF_CF } \\
\hline \multicolumn{7}{|c|}{ Dependent variable: net debt issues scaled by net assets } \\
\hline & \multicolumn{2}{|c|}{ Full sample (models 1-2) } & \multicolumn{2}{|c|}{ DEF_CF>0 (models 3-4) } & \multicolumn{2}{|c|}{ DEF_CF $<0$ (models 5-6) } \\
\hline & $(1)$ & $(2)$ & (3) & $(4)$ & (5) & $(6)$ \\
\hline \multirow[t]{2}{*}{$D E F$} & $0.393^{* * *}$ & $0.380 * * *$ & $0.280 * * *$ & $0.269 * * *$ & $0.558 * * *$ & $0.557 * * *$ \\
\hline & $(0.000)$ & $(0.000)$ & $(0.000)$ & $(0.000)$ & $(0.000)$ & $(0.000)$ \\
\hline \multirow[t]{2}{*}{$I A I R \_D$} & $0.048 * * *$ & & $0.062 * * *$ & & 0.016 & \\
\hline & $(0.000)$ & & $(0.000)$ & & $(0.163)$ & \\
\hline \multirow[t]{2}{*}{$I A I R \_D * D E F$} & $-0.175 * * *$ & & $-0.126 * * *$ & & 0.016 & \\
\hline & $(0.000)$ & & $(0.001)$ & & $(0.927)$ & \\
\hline$I A I R \_R E S \_D$ & & $0.024 * *$ & & $0.033 * *$ & & 0.009 \\
\hline & & $(0.014)$ & & $(0.018)$ & & $(0.434)$ \\
\hline$I A I R \_R E S \_D * D E F$ & & $-0.129 * * *$ & & $-0.097 * * *$ & & 0.014 \\
\hline & & $(0.001)$ & & $(0.008)$ & & $(0.923)$ \\
\hline$\Delta M B$ & -0.001 & -0.001 & 0.002 & 0.002 & -0.003 & -0.004 \\
\hline & $(0.838)$ & $(0.753)$ & $(0.605)$ & $(0.707)$ & $(0.336)$ & $(0.301)$ \\
\hline$\Delta$ Firm size & $0.026 * *$ & $0.028 * *$ & $0.038 * *$ & $0.040 * *$ & -0.020 & -0.020 \\
\hline & $(0.032)$ & $(0.026)$ & $(0.032)$ & $(0.024)$ & $(0.291)$ & $(0.303)$ \\
\hline$\Delta$ Tangibility & 0.077 & 0.065 & 0.020 & 0.032 & 0.063 & 0.059 \\
\hline & $(0.306)$ & (0.369) & $(0.853)$ & $(0.763)$ & $(0.280)$ & $(0.298)$ \\
\hline$\Delta$ Profitability & $-0.144 * * *$ & $-0.151 * * *$ & $-0.138 * * *$ & $-0.140 * * *$ & -0.011 & -0.011 \\
\hline & $(0.000)$ & $(0.000)$ & $(0.002)$ & $(0.001)$ & $(0.670)$ & $(0.646)$ \\
\hline Within $\mathrm{R}^{2}$ & 0.466 & 0.444 & 0.328 & 0.306 & 0.330 & 0.329 \\
\hline Obs. & 2283 & 2246 & 1124 & 1113 & 1067 & 1042 \\
\hline
\end{tabular}




\section{Table 4 Alternative specifications: leverage regression}

This table examines the effects of both optimistic tone dummies (i.e. TONE_D and TONE_RES_D that are one if tone index and orthogonalized tone index are above their median respectively and zero otherwise) and industryadjusted investment rate dummies (i.e. $I A I R \_D$ and $I A I R \_R E S \_D$ ) on the pecking order preference using an alternative specification. Specifically, the dependent variable in the Shyam-Sunder and Myers (1999) regression is replaced with book leverage, defined as total debt scaled by total assets. Financing deficit is calculated using balance sheet data in Panel A and C, and using cash flow data in Panel B and D. Panel A and B examine the interaction between tone and DEF, while Panel $\mathrm{C}$ and $\mathrm{D}$ examine the interaction between industry-adjusted investment rate (IAIR) and DEF. Models 1-2 are based on the full sample, while models 3-4 and models 5-6 focus on firm-years observations with financing deficit (i.e. $D E F \_B S>0$ or $D E F \_C F>0$ ) and financing surplus (i.e. $D E F \_B S<0$ or $D E F \_C F<0$ ) respectively. Constants are included but not reported. All models are estimated using fixed effects within estimators. Robust standard errors are adjusted for firm-level clustering. P-values are given in parentheses. $* * *, * *$ and $*$ indicate that coefficient is significant at $1 \%, 5 \%$ and $10 \%$ levels, respectively. Panel A. The interaction between tone and DEF_BS

\begin{tabular}{|c|c|c|c|c|c|c|}
\hline \multicolumn{7}{|c|}{ Dependent variable: total debt/total assets } \\
\hline & \multicolumn{2}{|c|}{ Full sample(models 1-2) } & \multicolumn{2}{|c|}{ DEF_BS>0 (models 3-4) } & \multicolumn{2}{|c|}{ DEF_BS $<0$ (models 5-6) } \\
\hline & $(1)$ & $(2)$ & (3) & $(4)$ & $(5)$ & $(6)$ \\
\hline$D E F$ & $\begin{array}{c}0.034 * * * \\
(0.000)\end{array}$ & $\begin{array}{c}0.029 * * * \\
(0.000)\end{array}$ & $\begin{array}{c}0.036 * * * \\
(0.000)\end{array}$ & $\begin{array}{c}0.028 * * * \\
(0.000)\end{array}$ & $\begin{array}{c}0.041^{* *} \\
(0.050)\end{array}$ & $\begin{array}{c}0.055 * * * \\
(0.005)\end{array}$ \\
\hline TONE_D & $\begin{array}{c}-0.015 * * * \\
(0.000)\end{array}$ & & $\begin{array}{c}-0.010^{*} \\
(0.053)\end{array}$ & & $\begin{array}{c}-0.027 * * * \\
(0.002)\end{array}$ & \\
\hline TONE_D*DEF & $\begin{array}{l}-0.014 * \\
(0.075)\end{array}$ & & $\begin{array}{c}-0.019 * \\
(0.077)\end{array}$ & & $\begin{array}{l}-0.046 \\
(0.112)\end{array}$ & \\
\hline TONE_RES_D & & $\begin{array}{c}-0.014^{* * *} \\
(0.000)\end{array}$ & & $\begin{array}{c}-0.009 * \\
(0.050)\end{array}$ & & $\begin{array}{c}-0.036 * * * \\
(0.000)\end{array}$ \\
\hline$T O N E \_R E S \_D * D E F$ & & $\begin{array}{l}-0.007 \\
(0.240)\end{array}$ & & $\begin{array}{l}-0.010 \\
(0.149)\end{array}$ & & $\begin{array}{c}-0.081^{* * * *} \\
(0.006)\end{array}$ \\
\hline Controls & Yes & Yes & Yes & Yes & Yes & Yes \\
\hline Within $\mathrm{R}^{2}$ & 0.061 & 0.055 & 0.059 & 0.048 & 0.062 & 0.079 \\
\hline Obs. & 2283 & 2283 & 1451 & 1451 & 832 & 832 \\
\hline \multicolumn{7}{|c|}{ Panel B. The interaction between tone and DEF_CF } \\
\hline \multicolumn{7}{|c|}{ Dependent variable: total debt/total assets } \\
\hline & Full sampl & odels 1-2) & DEF_CF $>$ & odels 3-4) & DEF_CF $<$ & odels 5-6) \\
\hline & $(1)$ & $(2)$ & (3) & $(4)$ & $(5)$ & $(6)$ \\
\hline$D E F$ & $\begin{array}{c}0.078 * * * \\
(0.000)\end{array}$ & $\begin{array}{c}0.064^{* * * *} \\
(0.000)\end{array}$ & $\begin{array}{c}0.063^{* * *} \\
(0.000)\end{array}$ & $\begin{array}{c}0.046^{* * *} \\
(0.000)\end{array}$ & $\begin{array}{c}0.064 \\
(0.339)\end{array}$ & $\begin{array}{c}0.063 \\
(0.370)\end{array}$ \\
\hline TONE_D & $\begin{array}{c}-0.014 * * * \\
(0.000)\end{array}$ & & $\begin{array}{c}-0.011^{* *} \\
(0.010)\end{array}$ & & $\begin{array}{c}-0.020^{* *} \\
(0.012)\end{array}$ & \\
\hline$T O N E \_D * D E F$ & $\begin{array}{c}-0.048 * * * \\
(0.006)\end{array}$ & & $\begin{array}{c}-0.042 * * \\
(0.021)\end{array}$ & & $\begin{array}{l}-0.013 \\
(0.865)\end{array}$ & \\
\hline TONE_RES_D & & $\begin{array}{c}-0.012 * * * \\
(0.001)\end{array}$ & & $\begin{array}{c}-0.010 * * \\
(0.031)\end{array}$ & & $\begin{array}{c}-0.022 * * * \\
(0.004)\end{array}$ \\
\hline TONE_RES_D*DEF & & $\begin{array}{c}-0.032^{* *} \\
(0.017)\end{array}$ & & $\begin{array}{c}-0.025^{*} \\
(0.058)\end{array}$ & & $\begin{array}{l}-0.003 \\
(0.972)\end{array}$ \\
\hline Controls & Yes & Yes & Yes & Yes & Yes & Yes \\
\hline Within $\mathrm{R}^{2}$ & 0.066 & 0.056 & 0.057 & 0.042 & 0.062 & 0.067 \\
\hline Obs. & 2283 & 2283 & 1124 & 1124 & 1067 & 1067 \\
\hline
\end{tabular}

\section{(Continuing on the next page)}


(Continued from the previous page)

\begin{tabular}{|c|c|c|c|c|c|c|}
\hline \multicolumn{7}{|c|}{ Panel C. The interaction between IAIR and DEF_BS } \\
\hline \multicolumn{7}{|c|}{ Dependent variable: total debt/total assets } \\
\hline & \multicolumn{2}{|c|}{ Full sample(models 1-2) } & \multicolumn{2}{|c|}{ DEF_BS >0 (models 3-4) } & \multicolumn{2}{|c|}{ DEF_BS $<0$ (models 5-6) } \\
\hline & (1) & (2) & (3) & (4) & (5) & (6) \\
\hline DEF & $\begin{array}{c}0.028 * * * \\
(0.000)\end{array}$ & $\begin{array}{c}0.027 * * * \\
(0.000)\end{array}$ & $\begin{array}{c}0.027 * * * \\
(0.000)\end{array}$ & $\begin{array}{c}0.025 * * * \\
(0.000)\end{array}$ & $\begin{array}{c}0.015 \\
(0.381)\end{array}$ & $\begin{array}{c}0.016 \\
(0.349)\end{array}$ \\
\hline$I A I R \_D$ & $\begin{array}{c}0.002 \\
(0.739)\end{array}$ & & $\begin{array}{l}0.016^{*} \\
(0.067)\end{array}$ & & $\begin{array}{l}-0.004 \\
(0.839)\end{array}$ & \\
\hline$I A I R \_D * D E F$ & $\begin{array}{c}-0.017 * * * \\
(0.007)\end{array}$ & & $\begin{array}{c}-0.020 * * * \\
(0.004)\end{array}$ & & $\begin{array}{c}0.042 \\
(0.401)\end{array}$ & \\
\hline$I A I R \_R E S \_D$ & & $\begin{array}{c}0.007 \\
(0.294)\end{array}$ & & $\begin{array}{c}0.016^{* *} \\
(0.024)\end{array}$ & & $\begin{array}{c}-0.011 \\
(0.522)\end{array}$ \\
\hline$I A I R \_R E S \_D * D E F$ & & $\begin{array}{c}-0.016 * * \\
(0.012)\end{array}$ & & $\begin{array}{c}-0.017 * * \\
(0.014)\end{array}$ & & $\begin{array}{c}0.009 \\
(0.842)\end{array}$ \\
\hline Controls & Yes & Yes & Yes & Yes & Yes & Yes \\
\hline Within $\mathrm{R}^{2}$ & 0.048 & 0.046 & 0.044 & 0.041 & 0.041 & 0.040 \\
\hline Obs. & 2283 & 2246 & 1451 & 1434 & 832 & 812 \\
\hline \multicolumn{7}{|c|}{ Panel D. The interaction between IAIR and DEF_CF } \\
\hline \multicolumn{7}{|c|}{ Dependent variable: total debt/total assets } \\
\hline & Full sampl & odels 1-2) & DEF_CF> & iodels 3-4) & DEF_CF $<$ & odels 5-6) \\
\hline & $(1)$ & $(2)$ & (3) & (4) & (5) & $(6)$ \\
\hline$D E F$ & $\begin{array}{c}0.056^{* * *} \\
(0.000)\end{array}$ & $\begin{array}{c}0.056 * * * \\
(0.000)\end{array}$ & $\begin{array}{c}0.044^{* * * *} \\
(0.000)\end{array}$ & $\begin{array}{c}0.044 * * * \\
(0.000)\end{array}$ & $\begin{array}{c}0.126^{* * *} \\
(0.001)\end{array}$ & $\begin{array}{c}0.143^{* * *} \\
(0.001)\end{array}$ \\
\hline$I A I R \_D$ & $\begin{array}{c}0.005 \\
(0.485)\end{array}$ & & $\begin{array}{c}0.013 \\
(0.145)\end{array}$ & & $\begin{array}{c}-0.041^{*} \\
(0.067)\end{array}$ & \\
\hline$I A I R \_D * D E F$ & $\begin{array}{c}-0.045^{* * *} \\
(0.000)\end{array}$ & & $\begin{array}{c}-0.045 * * * \\
(0.000)\end{array}$ & & $\begin{array}{l}-0.231 \\
(0.250)\end{array}$ & \\
\hline$I A I R \_R E S \_D$ & & $\begin{array}{c}0.009 \\
(0.159)\end{array}$ & & $\begin{array}{c}0.011 \\
(0.174)\end{array}$ & & $\begin{array}{l}-0.020 \\
(0.223)\end{array}$ \\
\hline$I A I R \_R E S \_D * D E F$ & & $\begin{array}{c}-0.044 * * * \\
(0.000)\end{array}$ & & $\begin{array}{c}-0.042 * * * \\
(0.000)\end{array}$ & & $\begin{array}{c}-0.234 * \\
(0.068)\end{array}$ \\
\hline Controls & Yes & Yes & Yes & Yes & Yes & Yes \\
\hline Within $\mathrm{R}^{2}$ & 0.052 & 0.050 & 0.051 & 0.050 & 0.042 & 0.041 \\
\hline Obs. & 2283 & 2246 & 1124 & 1113 & 1067 & 1042 \\
\hline
\end{tabular}




\section{Table 5 The effect of earnings volatility on the relationship between managerial overconfidence and pecking order preference}

This table examines whether the effect of managerial overconfidence on the pecking order preference depends on earnings volatility. Earnings volatility is defined as the standard deviation of the first difference in EBITD in the past five years (at least three years), scaled by the average book value of assets. We therefore compare the results from two subsamples divided by earnings volatility. The dependent variable is net debt issues scaled by net assets. Panel A compares the effects of tone on the pecking order preference of firms with high and low earnings volatility. Models 1-4 in Panel A are based on the subsample including firms with earnings volatility above its median and models 5-8 in Panel A are based on the subsample including firms with earnings volatility below its median. Panel B compares the effects of industry-adjusted investment rate on the pecking order preference of firms with high and low earnings volatility. Models 1-2 in Panel B are based on the subsample including firms with earnings volatility above its median and models 3-4 in Panel B are based on the subsample including firms with earnings volatility below its median. DEF_BS indicates that financing deficit and net debt issues are calculated using balance sheet data. $D E F \_C F$ indicates that financing deficit and net debt issues are calculated using cash flow data. Constants are included but not reported. All models are estimated using fixed effects within estimators. Robust standard errors are adjusted for firm-level clustering. P-values are given in parentheses. $* * *, * *$ and $*$ indicate that coefficient is significant at $1 \%, 5 \%$ and $10 \%$ levels, respectively.

Panel A. The interactions between tone and both DEF_BS and DEF_CF

Dependent variable: net debt issues scaled by net assets

\begin{tabular}{|c|c|c|c|c|c|c|c|c|}
\hline & \multicolumn{4}{|c|}{ Firms with high earnings volatility (models 1-4) } & \multicolumn{4}{|c|}{ Firms with low earnings volatility (models 5-8) } \\
\hline & DEF_BS & odel 1-2) & DEF_CF & odel 3-4) & DEF_BS & codel 5-6) & DEF_CF & odel 7-8) \\
\hline & (1) & $(2)$ & (3) & (4) & (5) & $(6)$ & (7) & (8) \\
\hline$D E F$ & $\begin{array}{c}0.515^{* * *} \\
(0.000)\end{array}$ & $\begin{array}{c}0.499 * * * \\
(0.000)\end{array}$ & $\begin{array}{c}0.776 * * * \\
(0.000)\end{array}$ & $\begin{array}{c}0.717^{* * *} \\
(0.000)\end{array}$ & $\begin{array}{c}0.780^{* * *} \\
(0.000)\end{array}$ & $\begin{array}{c}0.774^{* * *} \\
(0.000)\end{array}$ & $\begin{array}{c}0.819 * * * \\
(0.000)\end{array}$ & $\begin{array}{c}0.809 * * * \\
(0.000)\end{array}$ \\
\hline TONE_D & $\begin{array}{l}-0.005 \\
(0.808)\end{array}$ & & $\begin{array}{c}0.035 \\
(0.110)\end{array}$ & & $\begin{array}{c}0.024 * * \\
(0.019)\end{array}$ & & $\begin{array}{c}0.053 * * \\
(0.011)\end{array}$ & \\
\hline TONE_D*DEF & $\begin{array}{l}-0.075 \\
(0.239)\end{array}$ & & $\begin{array}{c}-0.239 * \\
(0.096)\end{array}$ & & $\begin{array}{c}-0.041 \\
(0.348)\end{array}$ & & $\begin{array}{c}0.022 \\
(0.882)\end{array}$ & \\
\hline TONE_RES_D & & $\begin{array}{c}0.006 \\
(0.780)\end{array}$ & & $\begin{array}{c}0.042 * \\
(0.069)\end{array}$ & & $\begin{array}{c}0.026 * * * \\
(0.007)\end{array}$ & & $\begin{array}{c}0.045 * * \\
(0.023)\end{array}$ \\
\hline TONE_RES_D*DEF & & $\begin{array}{c}-0.047 \\
(0.475)\end{array}$ & & $\begin{array}{c}-0.144 \\
(0.264)\end{array}$ & & $\begin{array}{l}-0.037 \\
(0.390)\end{array}$ & & $\begin{array}{c}0.042 \\
(0.760)\end{array}$ \\
\hline Controls & Yes & Yes & Yes & Yes & Yes & Yes & Yes & Yes \\
\hline Within $\mathrm{R}^{2}$ & 0.576 & 0.573 & 0.372 & 0.365 & 0.895 & 0.895 & 0.516 & 0.515 \\
\hline Obs. & 1095 & 1095 & 1095 & 1095 & 1095 & 1095 & 1095 & 1095 \\
\hline
\end{tabular}

Dependent variable: net debt issues scaled by net assets

\begin{tabular}{|c|c|c|c|c|c|c|c|c|}
\hline & \multicolumn{4}{|c|}{ Firms with high earnings volatility (models 1-4) } & \multicolumn{4}{|c|}{ Firms with low earnings volatility (models 5-8) } \\
\hline & \multicolumn{2}{|c|}{ DEF_BS } & \multicolumn{2}{|c|}{ DEF_CF } & \multicolumn{2}{|c|}{ DEF_BS } & \multicolumn{2}{|c|}{ DEF_CF } \\
\hline & (1) & $(2)$ & (3) & (4) & (5) & $(6)$ & $(7)$ & $(8)$ \\
\hline$D E F$ & $\begin{array}{c}0.512^{* * *} \\
(0.000)\end{array}$ & $\begin{array}{c}0.479 * * * \\
(0.000)\end{array}$ & $\begin{array}{c}0.317 * * * \\
(0.000)\end{array}$ & $\begin{array}{c}0.305^{* * * *} \\
(0.000)\end{array}$ & $\begin{array}{c}0.750^{* * * *} \\
(0.000)\end{array}$ & $\begin{array}{c}0.745^{* * * *} \\
(0.000)\end{array}$ & $\begin{array}{c}0.676 * * * \\
(0.000)\end{array}$ & $\begin{array}{c}0.662 * * * \\
(0.000)\end{array}$ \\
\hline$I A I R \_D$ & $\begin{array}{c}0.028 \\
(0.430)\end{array}$ & & $\begin{array}{l}0.030 * * \\
(0.026)\end{array}$ & & $\begin{array}{c}0.050 * * \\
(0.038)\end{array}$ & & $\begin{array}{l}0.023 * \\
(0.068)\end{array}$ & \\
\hline$I A I R \_D * D E F$ & $\begin{array}{l}-0.185^{*} \\
(0.085)\end{array}$ & & $\begin{array}{c}-0.134^{* * *} * \\
(0.005)\end{array}$ & & $\begin{array}{c}0.000 \\
(0.994)\end{array}$ & & $\begin{array}{c}0.001 \\
(0.994)\end{array}$ & \\
\hline$I A I R \_R E S \_D$ & & $\begin{array}{c}-0.013 \\
(0.692)\end{array}$ & & $\begin{array}{c}0.014 \\
(0.280)\end{array}$ & & $\begin{array}{c}0.021 \\
(0.279)\end{array}$ & & $\begin{array}{c}0.009 \\
(0.362)\end{array}$ \\
\hline$I A I R \_R E S \_D * D E F$ & & $\begin{array}{c}-0.072 \\
(0.497)\end{array}$ & & $\begin{array}{c}-0.101 * * \\
(0.036)\end{array}$ & & $\begin{array}{c}0.026 \\
(0.643)\end{array}$ & & $\begin{array}{c}0.075 \\
(0.284)\end{array}$ \\
\hline Controls & Yes & Yes & Yes & Yes & Yes & Yes & Yes & Yes \\
\hline Within $\mathrm{R}^{2}$ & 0.589 & 0.565 & 0.416 & 0.391 & 0.895 & 0.896 & 0.773 & 0.772 \\
\hline Obs. & 1095 & 1082 & 1095 & 1082 & 1095 & 1071 & 1095 & 1071 \\
\hline
\end{tabular}




\section{Table 6 The effect of firm size on the relationship between managerial overconfidence and pecking order preference}

This table examines whether the effect of managerial overconfidence on the pecking order preference depends on firm size. We therefore compare the results from two subsamples divided by firm size. The dependent variable is net debt issues scaled by net assets. Panel A compares the effects of tone on the pecking order preference of small and large firms. Models 1-4 in Panel A are based on the subsample including small firms with firm size below its median and models 5-8 in Panel A are based on the subsample including large firms with firm size above its median. Panel B compares the effects of industry-adjusted investment rate on the pecking order preference of small and large firms. Models 1-2 in Panel B are based on the subsample including small firms with firm size below its median and models 3-4 in Panel B are based on the subsample including large firms with firm size above its median. $D E F \_B S$ indicates that financing deficit and net debt issues are calculated using balance sheet data. DEF_CF indicates that financing deficit and net debt issues are calculated using cash flow data. Constants are included but not reported. All models are estimated using fixed effects within estimators. Robust standard errors are adjusted for firm-level clustering. P-values are given in parentheses. ***, ** and * indicate that coefficient is significant at $1 \%, 5 \%$ and $10 \%$ levels, respectively.

\begin{tabular}{|c|c|c|c|c|c|c|c|c|}
\hline \multicolumn{9}{|c|}{ Panel A. The interactions between tone and both $D E F \_B S$ and $D E F \_C F$} \\
\hline \multicolumn{9}{|c|}{ Dependent variable: net debt issues scaled by net assets } \\
\hline & \multicolumn{4}{|c|}{ Small firms (models 1-4) } & \multicolumn{4}{|c|}{ Large firms (models 5-8) } \\
\hline & \multicolumn{2}{|c|}{ DEF_BS (models 1-2) } & \multicolumn{2}{|c|}{ DEF_CF (models 3-4) } & \multicolumn{2}{|c|}{ DEF_BS (models 5-6) } & \multicolumn{2}{|c|}{ DEF_CF (models 7-8) } \\
\hline & (1) & (2) & (3) & (4) & (5) & (6) & (7) & (8) \\
\hline DEF & $\begin{array}{c}0.501 * * * \\
(0.000)\end{array}$ & $\begin{array}{c}0.451 * * * \\
(0.000)\end{array}$ & $\begin{array}{c}0.661 * * * \\
(0.000)\end{array}$ & $\begin{array}{c}0.539 * * * \\
(0.000)\end{array}$ & $\begin{array}{c}0.769 * * * \\
(0.000)\end{array}$ & $\begin{array}{c}0.760 * * * \\
(0.000)\end{array}$ & $\begin{array}{c}0.911 * * * \\
(0.000)\end{array}$ & $\begin{array}{c}0.927 * * * \\
(0.000)\end{array}$ \\
\hline TONE_D & $\begin{array}{c}0.000 \\
(0.991)\end{array}$ & & $\begin{array}{c}0.050^{* *} \\
(0.044)\end{array}$ & & $\begin{array}{c}0.038 * * * \\
(0.000)\end{array}$ & & $\begin{array}{c}0.042 * * \\
(0.042)\end{array}$ & \\
\hline$T O N E \_D * D E F$ & $\begin{array}{c}-0.131 * * * \\
(0.010)\end{array}$ & & $\begin{array}{c}-0.324^{* * *} \\
(0.002)\end{array}$ & & $\begin{array}{l}-0.070^{*} \\
(0.099)\end{array}$ & & $\begin{array}{c}0.063 \\
(0.545)\end{array}$ & \\
\hline TONE_RES_D & & $\begin{array}{c}0.014 \\
(0.486)\end{array}$ & & $\begin{array}{c}0.053^{* *} \\
(0.026)\end{array}$ & & $\begin{array}{c}0.032 * * * \\
(0.000)\end{array}$ & & $\begin{array}{c}0.024 \\
(0.180)\end{array}$ \\
\hline$T O N E \_R E S \_D * D E F$ & & $\begin{array}{c}-0.051 \\
(0.407)\end{array}$ & & $\begin{array}{c}-0.153 \\
(0.180)\end{array}$ & & $\begin{array}{c}-0.063 \\
(0.186)\end{array}$ & & $\begin{array}{c}0.047 \\
(0.664)\end{array}$ \\
\hline Controls & Yes & Yes & Yes & Yes & Yes & Yes & Yes & Yes \\
\hline Within $\mathrm{R}^{2}$ & 0.529 & 0.517 & 0.264 & 0.244 & 0.882 & 0.881 & 0.562 & 0.560 \\
\hline Obs. & 1141 & 1141 & 1141 & 1141 & 1142 & 1142 & 1142 & 1142 \\
\hline \multicolumn{9}{|c|}{ Panel B. The interactions between IAIR and both $D E F \_B S$ and DEF_CF } \\
\hline \multicolumn{9}{|c|}{ Dependent variable: net debt issues scaled by net assets } \\
\hline & \multicolumn{4}{|c|}{ Small firms (models 1-4) } & \multicolumn{4}{|c|}{ Large firms (models 5-6) } \\
\hline & \multicolumn{2}{|c|}{ DEF_BS (models 1-2) } & \multicolumn{2}{|c|}{ DEF_CF (models 3-4) } & \multicolumn{2}{|c|}{ DEF_BS (models 5-6) } & \multicolumn{2}{|c|}{ DEF_CF (models 7-8) } \\
\hline & $(1)$ & $(2)$ & (3) & $(4)$ & (5) & $(6)$ & $(7)$ & $(8)$ \\
\hline$D E F$ & $\begin{array}{c}0.444 * * * \\
(0.000)\end{array}$ & $\begin{array}{c}0.439 * * * \\
(0.000)\end{array}$ & $\begin{array}{c}0.254 * * * \\
(0.000)\end{array}$ & $\begin{array}{c}0.245 * * * \\
(0.000)\end{array}$ & $\begin{array}{c}0.747 * * * \\
(0.000)\end{array}$ & $\begin{array}{c}0.734^{* * *} \\
(0.000)\end{array}$ & $\begin{array}{c}0.604 * * * \\
(0.000)\end{array}$ & $\begin{array}{c}0.607 * * * \\
(0.000)\end{array}$ \\
\hline$I A I R \_D$ & $\begin{array}{c}0.028 \\
(0.334)\end{array}$ & & $\begin{array}{c}0.028 * * * \\
(0.008)\end{array}$ & & $\begin{array}{c}0.064 \\
(0.133)\end{array}$ & & $\begin{array}{c}0.020 \\
(0.249)\end{array}$ & \\
\hline$I A I R \_D * D E F$ & $\begin{array}{c}-0.073 \\
(0.387)\end{array}$ & & $\begin{array}{c}-0.127 * * * \\
(0.000)\end{array}$ & & $\begin{array}{c}-0.139 \\
(0.258)\end{array}$ & & $\begin{array}{c}-0.034 \\
(0.727)\end{array}$ & \\
\hline$I A I R \_R E S \_D$ & & $\begin{array}{c}0.038 \\
(0.179)\end{array}$ & & $\begin{array}{c}0.026^{* *} \\
(0.013)\end{array}$ & & $\begin{array}{l}-0.010 \\
(0.520)\end{array}$ & & $\begin{array}{l}-0.000 \\
(0.972)\end{array}$ \\
\hline$I A I R \_R E S \_D * D E F$ & & $\begin{array}{l}-0.082 \\
(0.354)\end{array}$ & & $\begin{array}{c}-0.116 * * * \\
(0.000)\end{array}$ & & $\begin{array}{l}-0.015 \\
(0.686)\end{array}$ & & $\begin{array}{l}-0.018 \\
(0.836)\end{array}$ \\
\hline Controls & Yes & Yes & Yes & Yes & Yes & Yes & Yes & Yes \\
\hline Within $\mathrm{R}^{2}$ & 0.518 & 0.508 & 0.310 & 0.304 & 0.883 & 0.904 & 0.709 & 0.702 \\
\hline Obs. & 1141 & 1130 & 1141 & 1130 & 1142 & 1116 & 1142 & 1116 \\
\hline
\end{tabular}




\section{Table 7 Net purchase of CEO and CFO and pecking order preference}

This table examines the effect of CEO/CFO net purchase dummies (i.e. CEO_NPRD and CFO_NPRD that are one if the net purchase ratio (NPR) of CEO and CFO are 1 and zero otherwise) on the pecking order preference by looking at the interaction between CEO/CFO net purchase dummies and financing deficit (DEF) in the Shyam-Sunder and Myers (1999) financing deficit regression framework. The dependent variable is net debt issues scaled by net assets. Financing deficit and net debt issues are calculated using balance sheet data in Panel A. Models 1-2 in Panel A are based on the full sample, while models 3-4 and models 5-6 in Panel A focus on firm-years observations with financing deficit (i.e. $D E F \_B S>0$ ) and financing surplus (i.e. $D E F \_B S<0$ ) respectively. Financing deficit and net debt issues are calculated using cash flow data in Panel B. Models 1-2 in Panel B are based on the full sample, while models 3-4 and models 5-6 in Panel B focus on firm-years observations with financing deficit (i.e. $D E F \_C F>0$ ) and financing surplus (i.e. $D E F \_C F<0$ ) respectively. Constants are included but not reported. All models are estimated using fixed effects within estimators. Robust standard errors are adjusted for firm-level clustering. P-values are given in parentheses. ***, ** and * indicate that coefficient is significant at $1 \%, 5 \%$ and $10 \%$ levels, respectively.

\begin{tabular}{|c|c|c|c|c|c|c|}
\hline \multicolumn{7}{|c|}{ Panel A. The interaction between net purchases and DEF_BS } \\
\hline \multicolumn{7}{|c|}{ Dependent variable: net debt issues scaled by net assets } \\
\hline & \multicolumn{2}{|c|}{ Full sample (models 1-2) } & \multicolumn{2}{|c|}{ DEF_BS $>0$ (models 3-4) } & \multicolumn{2}{|c|}{ DEF_BS<0 (models 5-6) } \\
\hline & $(1)$ & $(2)$ & $(3)$ & (4) & $(5)$ & $(6)$ \\
\hline DEF & $\begin{array}{c}0.579 * * * \\
(0.000)\end{array}$ & $\begin{array}{c}0.705^{* * * *} \\
(0.000)\end{array}$ & $\begin{array}{c}0.584 * * * \\
(0.000)\end{array}$ & $\begin{array}{c}0.697 * * * \\
(0.000)\end{array}$ & $\begin{array}{c}0.257 * * \\
(0.034)\end{array}$ & $\begin{array}{c}0.236 \\
(0.439)\end{array}$ \\
\hline CEO_NPRD & $\begin{array}{c}0.003 \\
(0.680)\end{array}$ & & $\begin{array}{c}-0.001 \\
(0.905)\end{array}$ & & $\begin{array}{l}-0.005 \\
(0.677)\end{array}$ & \\
\hline$C E O \_N P R D * D E F$ & $\begin{array}{c}0.022 \\
(0.691)\end{array}$ & & $\begin{array}{c}0.076 \\
(0.131)\end{array}$ & & $\begin{array}{l}-0.024 \\
(0.863)\end{array}$ & \\
\hline CFO_NPRD & & $\begin{array}{c}0.003 \\
(0.719)\end{array}$ & & $\begin{array}{c}0.004 \\
(0.651)\end{array}$ & & $\begin{array}{c}-0.001 \\
(0.960)\end{array}$ \\
\hline CFO_NPRD*DEF & & $\begin{array}{l}-0.091 * \\
(0.064)\end{array}$ & & $\begin{array}{l}-0.098 * \\
(0.083)\end{array}$ & & $\begin{array}{c}0.170 \\
(0.579)\end{array}$ \\
\hline Controls & Yes & Yes & Yes & Yes & Yes & Yes \\
\hline Within $\mathrm{R}^{2}$ & 0.706 & 0.757 & 0.740 & 0.772 & 0.219 & 0.505 \\
\hline Obs. & 1327 & 1071 & 843 & 680 & 484 & 391 \\
\hline \multicolumn{7}{|c|}{ Panel B. The interaction between net purchases and DEF_CF } \\
\hline \multicolumn{7}{|c|}{ Dependent variable: net debt issues scaled by net assets } \\
\hline & Full samp & dels 1-2) & DEF_CF> & dels 3-4) & DEF_CF & dels 5-6) \\
\hline & $(1)$ & $(2)$ & $(3)$ & $(4)$ & $(5)$ & $(6)$ \\
\hline$\overline{D E F}$ & $\begin{array}{c}0.404 * * * \\
(0.000)\end{array}$ & $\begin{array}{c}0.503 * * * \\
(0.000)\end{array}$ & $\begin{array}{c}0.249 * * * \\
(0.004)\end{array}$ & $\begin{array}{c}0.425 * * * \\
(0.000)\end{array}$ & $\begin{array}{c}0.697 * * * \\
(0.000)\end{array}$ & $\begin{array}{c}0.655^{* * *} \\
(0.000)\end{array}$ \\
\hline CEO_NPRD & $\begin{array}{l}-0.004 \\
(0.317)\end{array}$ & & $\begin{array}{c}-0.011 \\
(0.21)\end{array}$ & & $\begin{array}{l}-0.006 \\
(0.183)\end{array}$ & \\
\hline CEO_NPRD*DEF & $\begin{array}{c}0.045 \\
(0.638)\end{array}$ & & $\begin{array}{c}0.114 \\
(0.284)\end{array}$ & & $\begin{array}{c}-0.049 \\
(0.658)\end{array}$ & \\
\hline CFO_NPRD & & $\begin{array}{c}0.002 \\
(0.654)\end{array}$ & & $\begin{array}{l}-0.002 \\
(0.798)\end{array}$ & & $\begin{array}{c}0.000 \\
(0.934)\end{array}$ \\
\hline CFO_NPRD*DEF & & $\begin{array}{c}-0.072 \\
(0.380)\end{array}$ & & $\begin{array}{l}-0.123 \\
(0.228)\end{array}$ & & $\begin{array}{l}-0.177 \\
(0.529)\end{array}$ \\
\hline Controls & Yes & Yes & Yes & Yes & Yes & Yes \\
\hline Within $\mathrm{R}^{2}$ & 0.544 & 0.522 & 0.446 & 0.449 & 0.467 & 0.244 \\
\hline Obs. & 1327 & 1071 & 649 & 523 & 623 & 515 \\
\hline
\end{tabular}




\section{Table 8 Alternative overconfidence measures and pecking order preference}

This table examines the effect of $R \& D$ dummies (i.e. $R \& D \_D$ and $R \& D \_R E S \_D$ that are one if the $R \& D$-to-sales ratio and orthogonalized $R \& D$-to-sales ratio are in the top quintile in a particular fiscal year respectively and zero otherwise) on the pecking order preference by looking at the interaction between tone dummies and financing deficit (DEF) in the Shyam-Sunder and Myers (1999) financing deficit regression framework. The dependent variable is net debt issues scaled by net assets. Financing deficit and net debt issues are calculated using balance sheet and cash flow data in Panel A and B respectively. Models 1-2 are based on the full sample, while models 3-4 and models 5-6 focus on firm-years observations with financing deficit (i.e. $D E F \_B S>0$ or $D E F \_C F>0$ ) and financing surplus (i.e. $D E F \_B S<0$ or $D E F \_C F<0$ ) respectively. Constants are included but not reported. All models are estimated using fixed effects within estimators. Robust standard errors are adjusted for firm-level clustering. P-values are given in parentheses. ***, ** and * indicate that coefficient is significant at $1 \%, 5 \%$ and $10 \%$ levels, respectively.

\begin{tabular}{|c|c|c|c|c|c|c|}
\hline \multicolumn{7}{|c|}{ Panel A. The interaction between $R \& D$ and $D E F \_B S$} \\
\hline \multicolumn{7}{|c|}{ Dependent variable: net debt issues scaled by net assets } \\
\hline & \multicolumn{2}{|c|}{ Full sample (models 1-2) } & \multicolumn{2}{|c|}{ DEF_BS>0 (models 3-4) } & \multicolumn{2}{|c|}{ DEF_BS<0 (models 5-6) } \\
\hline & $(1)$ & $(2)$ & $(3)$ & $(4)$ & $(5)$ & $(6)$ \\
\hline$D E F$ & $\begin{array}{c}0.604^{* * * *} \\
(0.000)\end{array}$ & $\begin{array}{c}0.573 * * * \\
(0.000)\end{array}$ & $\begin{array}{c}0.613 * * * \\
(0.000)\end{array}$ & $\begin{array}{c}0.570 * * * \\
(0.000)\end{array}$ & $\begin{array}{c}0.273 * * * \\
(0.000)\end{array}$ & $\begin{array}{c}0.275^{* * *} \\
(0.000)\end{array}$ \\
\hline$R \& D \_D$ & $\begin{array}{c}0.060 * * \\
(0.019)\end{array}$ & & $\begin{array}{c}0.092 * * \\
(0.026)\end{array}$ & & $\begin{array}{l}-0.030 \\
(0.335)\end{array}$ & \\
\hline$R \& D \_D^{*} D E F$ & $\begin{array}{c}-0.216 * * * \\
(0.000)\end{array}$ & & $\begin{array}{c}-0.210 * * * \\
(0.002)\end{array}$ & & $\begin{array}{l}-0.145 \\
(0.265)\end{array}$ & \\
\hline$R \& D \_R E S \_D$ & & $\begin{array}{l}0.047 * \\
(0.075)\end{array}$ & & $\begin{array}{c}0.042 \\
(0.275)\end{array}$ & & $\begin{array}{l}-0.038 \\
(0.116)\end{array}$ \\
\hline$R \& D \_R E S \_D * D E F$ & & $\begin{array}{c}-0.112 * * \\
(0.039)\end{array}$ & & $\begin{array}{c}-0.071 \\
(0.274)\end{array}$ & & $\begin{array}{l}-0.149 \\
(0.254)\end{array}$ \\
\hline Controls & Yes & Yes & Yes & Yes & Yes & Yes \\
\hline Within $\mathrm{R}^{2}$ & 0.697 & 0.684 & 0.667 & 0.651 & 0.213 & 0.217 \\
\hline Obs. & 2251 & 2246 & 1436 & 1434 & 815 & 812 \\
\hline \multicolumn{7}{|c|}{ Panel B. The interaction between $R \& D$ and $D E F \_C F$} \\
\hline \multicolumn{7}{|c|}{ Dependent variable: net debt issues scaled by net assets } \\
\hline & Full samp & dels 1-2) & DEF_CF & dels 3-4) & DEF_CF & dels 5-6) \\
\hline & $(1)$ & $(2)$ & $(3)$ & $(4)$ & $(5)$ & $(6)$ \\
\hline$D E F$ & $\begin{array}{c}0.441 * * * \\
(0.000)\end{array}$ & $\begin{array}{c}0.399 * * * \\
(0.000)\end{array}$ & $\begin{array}{c}0.328 * * * \\
(0.000)\end{array}$ & $\begin{array}{c}0.288 * * * \\
(0.000)\end{array}$ & $\begin{array}{c}0.591 * * * \\
(0.000)\end{array}$ & $\begin{array}{c}0.588 * * * \\
(0.000)\end{array}$ \\
\hline$R \& D \_D$ & $\begin{array}{c}0.031 * * \\
(0.013)\end{array}$ & & $\begin{array}{c}0.030 \\
(0.175)\end{array}$ & & $\begin{array}{l}-0.014 * \\
(0.097)\end{array}$ & \\
\hline$R \& D \_D * D E F$ & $\begin{array}{c}-0.291^{* * *} \\
(0.000)\end{array}$ & & $\begin{array}{c}-0.262 * * * \\
(0.000)\end{array}$ & & $\begin{array}{l}-0.245 \\
(0.150)\end{array}$ & \\
\hline$R \& D \_R E S \_D$ & & $\begin{array}{l}0.023 * \\
(0.061)\end{array}$ & & $\begin{array}{c}0.023 \\
(0.291)\end{array}$ & & $\begin{array}{c}-0.011 \\
(0.239)\end{array}$ \\
\hline$R \& D \_R E S \_D * D E F$ & & $\begin{array}{c}-0.211 * * * \\
(0.000)\end{array}$ & & $\begin{array}{c}-0.195 * * * \\
(0.000)\end{array}$ & & $\begin{array}{l}-0.213 \\
(0.210)\end{array}$ \\
\hline Controls & Yes & Yes & Yes & Yes & Yes & Yes \\
\hline Within $\mathrm{R}^{2}$ & 0.493 & 0.460 & 0.374 & 0.335 & 0.335 & 0.334 \\
\hline Obs. & 2251 & 2246 & 1115 & 1113 & 1045 & 1042 \\
\hline
\end{tabular}




\section{Appendix 1 Variable definitions}

\begin{tabular}{|c|c|}
\hline Variable & Definition \\
\hline \multicolumn{2}{|c|}{ Panel A: Measures of managerial overconfidence } \\
\hline \multicolumn{2}{|c|}{ a) Content analysis-based measures (optimistic tone measures) } \\
\hline Net emotion & $\begin{array}{l}\text { Positive emotion minus negative emotion including (anxiety, anger and sadness) as } \\
\text { defined by LIWC }\end{array}$ \\
\hline Certain1 & $\begin{array}{l}\text { Measure of certainty (e.g. always, never) as one aspect of cognitive processes as defined } \\
\text { by LIWC }\end{array}$ \\
\hline Optimism & [praise+satisfaction+inspiration]-[blame+hardship+denial] as defined by Diction \\
\hline Certain2 & $\begin{array}{l}\text { [tenacity+leveling+collectives+insistence]-[numerical terms+ambivalence+self } \\
\text { reference+variety] as defined by Diction }\end{array}$ \\
\hline Tone_H & (positive-negative)/(positive+negative), using Henry’s (2008) word list \\
\hline Tone_LM & (positive-negative)/(positive+negative), using Loughran and McDonald's (2011) word list \\
\hline TONE_D & $\begin{array}{l}\text { A dummy variable that takes the value of one if the composite tone index (see equation 1) } \\
\text { is above the median and zero otherwise }\end{array}$ \\
\hline TONE_RES_D & $\begin{array}{l}\text { A dummy variable that takes the value of one if the orthogonalized tone index (see } \\
\text { equation 3) is above the median and zero otherwise }\end{array}$ \\
\hline \multicolumn{2}{|l|}{ b) Investment-based measures } \\
\hline$I A I R \_D$ & $\begin{array}{l}\text { A dummy variable that takes the value of one if the industry-adjusted investment rate } \\
\text { (IAIR) is in the top quintile in a particular fiscal year and zero otherwise. Industry- } \\
\text { adjusted investment rate is the ratio of capital expenditure to the beginning of year } \\
\text { property, plant and equipment }\end{array}$ \\
\hline$I A I R \_R E S \_D$ & $\begin{array}{l}\text { A dummy variable that takes the value of one if the orthogonalized industry-adjusted } \\
\text { investment rate (IAIR) is in the top quintile in a particular fiscal year and zero otherwise. } \\
\text { This variable is orthogonal to firm size, MB, profitability, tangibility, firm age, R\&D, } \\
\text { dividend dummy, leverage, cash ratio, and price performance. }\end{array}$ \\
\hline$R \& D \_D$ & $\begin{array}{l}\text { A dummy variable that takes the value of one if the R\&D-to-sales ratio is in the top } \\
\text { quintile in a particular fiscal year and zero otherwise. }\end{array}$ \\
\hline$R \& D \_R E S \_D$ & $\begin{array}{l}\text { A dummy variable that takes the value of one if the orthogonalized R\&D-to-sales ratio is } \\
\text { in the top quintile in a particular fiscal year and zero otherwise. This variable is orthogonal } \\
\text { to firm size, MB, profitability, tangibility, firm age, dividend dummy, leverage, cash ratio, } \\
\text { and price performance. }\end{array}$ \\
\hline \multicolumn{2}{|c|}{ c) Insider trading-based measures (i.e. net purchase ratio (NPR)=(buy - sell)/(buy + sell)) } \\
\hline CEO_NPRD & $\begin{array}{l}\text { A dummy variable that takes the value of one if the net purchase ratio of CEO } \\
\left(C E O \_N P R\right) \text { is } 1 \text { and zero otherwise }\end{array}$ \\
\hline CFO_NPRD & $\begin{array}{l}\text { A dummy variable that takes the value of one if the net purchase ratio of CFO } \\
\left(C F O \_N P R\right) \text { is } 1 \text { and zero otherwise }\end{array}$ \\
\hline \multicolumn{2}{|c|}{ Panel B:Dependent variable and measures of financing deficit (DEF) } \\
\hline DEF_CF & Financing deficit measured using aggregate cash flow data (i.e. $\Delta D+\Delta E$ ) \\
\hline Net debt issues $\left(\triangle D \_C F\right)$ & Long term borrowings minus reduction in long term debt \\
\hline Net equity issues $\left(\triangle E_{-} C F\right)$ & $\begin{array}{l}\text { Net proceeds from sale/issue of common and preferred stocks minus common/preferred } \\
\text { redeemed, retired, converted }\end{array}$ \\
\hline DEF_BS & Financing deficit measured using balance sheet data (i.e. $\Delta D+\Delta E=\Delta A-\Delta R E$ ) \\
\hline Net debt issues $\left(\triangle D \_B S\right)$ & Change in total assets minus change in book equity \\
\hline Net equity issues $\left(\Delta \bar{E} \_B S\right)$ & Change in book equity minus change in retained earnings \\
\hline \multicolumn{2}{|l|}{ Panel C: Firm characteristics } \\
\hline Leverage & Total debt divided by total assets \\
\hline Firm size & Natural logarithm of sales \\
\hline$M B$ & $\begin{array}{l}\text { The ratio of book value of total assets minus book value of equity plus market value of } \\
\text { equity to book value of total assets }\end{array}$ \\
\hline Profitability & Earnings before interest, taxes and depreciation divided by total assets \\
\hline Tangibility & Net property, plant and equipment divided by total assets \\
\hline Earnings volatility & $\begin{array}{l}\text { The standard deviation of the first difference in EBITD in the past five years (at least three } \\
\text { years), scaled by the average book value of assets }\end{array}$ \\
\hline Firm age & The natural logarithm of the number of months since the incorporate date \\
\hline$R \& D$ & $\begin{array}{l}\text { Research and development (R\&D) expenditures divided by sales (missing R\&D values are } \\
\text { set equal to zero) }\end{array}$ \\
\hline Dividend dummy & $\begin{array}{l}\text { A dummy variable that takes the value of one if common dividend is positive and zero } \\
\text { otherwise }\end{array}$ \\
\hline Cash ratio & Cash divided by total assets \\
\hline Price performance & The difference of natural logarithm of fiscal year-end share prices \\
\hline
\end{tabular}




\section{References}

Ataullah, A., Vivian, A. and Xu, B. (2017). Time-varying managerial overconfidence and corporate debt maturity structure, European Journal of Finance, forthcoming.

Baker, M. and Wurgler, J. (2002). Market timing and capital structure, Journal of Finance, $57(1), 1-32$.

Baker, M. and Wurgler, J. (2013). Behavioural Corporate Finance: An Updated Survey, in Constantinides, G., Harris, M., Stulz, R. (eds.), Handbook of the Economics of Finance, Vol. 2A: Corporate Finance. Amsterdam: North Holland, 357-413.

Bessler, W., Drobetz, W. and Grüninger, M.C. (2011). Information asymmetry and financing decisions, International Review of Finance, 11(1), 123-154.

Bharath, S., Pasquariello, P. and Wu, G. (2009). Does asymmetric information drive capital structure decisions?, Review of Financial Studies, 22, 3211-3243.

Brick, I.E. and Liao, R.C. (2017). The joint determinants of cash holdings and debt maturity: the case for financial constraints, Review of Quantitative Finance and Accounting, 48, 597-641.

Campbell, T.C., Gallmeyer, M., Johnson, S.A., Rutherford, J. and Stanley, B.W. (2011). CEO optimism and forced turnover, Journal of Financial Economics, 101(3), 695-712.

Chang, X. and Dasgupta, S. (2009). Target behavior and financing: how conclusive is the evidence? Journal of Finance, 64(4), 1767-1796.

Chirinko, R.S. and Singha, A.R. (2000). Testing static tradeoff against pecking order models of capital structure: a critical comment. Journal of Financial Economics, 58(3), 417425.

Davis, A.K., Ge, W., Matsumoto, D. and Zhang, L. (2015). The effect of managerial "style” on the tone of earnings conference calls, Review of Accounting Studies, forthcoming.

Davis, A.K., Piger, J.M. and Sedor, L.M. (2012). Beyond the numbers: measuring the information content of earnings press release language, Contemporary Accounting Research, 29(3), 845-868.

De Jong, A., Verbeek, M. and Verwijmeren, P. (2010). The impact of financing surpluses and large financing deficits on tests of the pecking order theory, Financial Management, 39(2), 733-756.

Donaldson, G. (1961). Corporate Debt Capacity: A Study of Corporate Debt Policy and the Determination of Corporate Debt Capacity, Boston, Division of Research, Harvard Graduate School of Business Administration.

Elliot, W.B., Koeter-Kant, J. and Warr, R.S. (2007). A valuation-based test of market timing, Journal of Corporate Finance, 13, 112-128.

Fama, E, and French, K.R. (2002). Testing tradeoff and pecking order predictions about dividends and debt, Review of Financial Studies, 15, 1-33.

Fama, E.F. and French, K.R. (2005). Financing decisions: who issues stock?, Journal of Financial Economics, 76(3), 549-582.

Frank, M., and Goyal, V. (2003). Testing the pecking order theory of capital structure, Journal of Financial Economics, 67, 217-248. 
Frank, M., and Goyal, V. (2008). Trade-off and pecking order theories of debt, in Espen Eckbo (editor) The Handbook of Empirical Corporate Finance, Elsevier Science, Chapter 12, 135-197.

Frank, M.Z. and Goyal, V.K. (2009). Capital structure decisions: which factors are reliably important?, Financial Management, 38(1), 1-37.

Galasso, A. and Simcoe, T.S. (2011). CEO overconfidence and innovation, Management Science, 57(8), 1469-1484.

Graham, J.R. and Harvey, C.R. (2001). The theory and practice of corporate finance: Evidence from the field, Journal of Financial Economics, 60(2), 187-243.

Hackbarth, D. (2008). Managerial traits and capital structure decisions, Journal of Financial and Quantitative Analysis, 43, 843-882.

Heaton, J.B. (2002). Managerial optimism and corporate finance, Financial Management, 31, 33-45.

Henry, E. (2008). Are investors influenced by how earnings press releases are written? Journal of Business Communication, 45(4), 363-407.

Hennessy, C.A. and Whited, T.M. (2005). Debt dynamics, Journal of Finance, 60, 1129-1165.

Hilary, G., Hsu, C., Segal, B. and Wang, R. (2016). The bright side of managerial overoptimism, Journal of Accounting and Economics, 62(1), 46-64.

Hirshleifer, D., Low, A. and Teoh, S.H. (2012). Are overconfident CEOs better innovators?, Journal of Finance, 67(4), 1457-1498.

Huang-Meier, W., Lambertides, N. and Steeley, J.M. (2016). Motives for corporate cash holdings: the CEO optimism effect, Review of Quantitative Finance and Accounting, 47(3), 699-732.

Huang, R. and Ritter, J.R. (2009). Testing theories of capital structure and estimating the speed of adjustment, Journal of Financial and Quantitative analysis, 44(2), 237-271.

Huang, X., Teoh, S.H. and Zhang, Y. (2013). Tone management, Accounting Review, 89(3), 1083-1113.

Jenter, D. (2005). Market timing and managerial portfolio decisions, Journal of Finance, 60, 1903-1949.

Jin, L. and Kothari, S.P. (2008). Effect of personal taxes on managers' decisions to sell their stock, Journal of Accounting and Economics, 46, 23-46.

Kayhan, A. and Titman, S. (2007). Firms' histories and their capital structures, Journal of Financial Economics, 83(1), 1-32.

Leary, M.T. and Roberts, M.R. (2010). The pecking order, debt capacity, and information asymmetry, Journal of Financial Economics, 95, 332-355.

Lin, Y.H., Hu, S.Y. and Chen, M.S. (2008). Testing pecking order prediction from the viewpoint of managerial optimism: Some empirical evidence from Taiwan, PacificBasin Finance Journal, 16(1), 160-181.

Li, F. (2010a). Textual analysis of corporate disclosures: a survey of the literature, Journal of Accounting Literature, 29, 143-165.

Li, F. (2010b). The information content of forward-looking statements in corporate filings-a naïve bayesian machine learning approach, Journal of Accounting Research, 48(5), 1049-1102. 
Loughran, T. and McDonald, B. (2011). When is a liability not a liability? Textual analysis, dictionaries, and 10-Ks, Journal of Finance, 66(1), 35-65.

Low, P.Y. and Chen, K.H. (2004). Diversification and capital structure: Some international evidence, Review of Quantitative Finance and Accounting, 23(1), 55-71.

Malmendier, U. and Tate, G. (2005). Does overconfidence affect corporate investment? CEO overconfidence measures revisited, European Financial Management, 11, 649-659.

Malmendier, U., Tate, G. and Yan, J. (2011). Overconfidence and early-life experiences: the effect of managerial traits on corporate financial policies, Journal of Finance, 66(5), 1687-1733.

Malmendier, U. and Zheng, H. (2012). Managerial duties and managerial biases, Working Paper, University of California, Berkeley.

Maung, M. (2014). Security issuances in hot and cold markets, Review of Pacific Basin Financial Markets and Policies, 17(03), 1-45.

Myers, S.C. (1984). The capital structure puzzle, Journal of Finance, 39(3), 575-592.

Myers, S.C. and Majluf, N.S. (1984). Corporate financing and investment decisions when firms have information that investors do not have, Journal of Financial Economics, 13(2), 187-221.

Rogers, J.L., Van Buskirk, A. and Zechman, S.L. (2011). Disclosure tone and shareholder litigation, Accounting Review, 86(6), 2155-2183.

Sánchez-Vidal, J. and Martín-Ugedo, J.F. (2005). Financing preferences of Spanish firms: Evidence on the pecking order theory, Review of Quantitative Finance and Accounting, 25(4), 341-355.

Schmeling, M. (2009). Investor sentiment and stock returns: Some international evidence, Journal of Empirical Finance, 16(3), 394-408.

Seifert B. and Gonenc, H. (2010). Pecking order behavior in emerging markets, Journal of International Financial Management and Accounting, 21(1), 1-31.

Shefrin, H. (2007). Behavioral Corporate Finance: Decisions That Create Value. Boston: McGraw-Hill/Irwin.

Shyam-Sunder, L. and Myers, S.C. (1999). Testing static tradeoff against pecking order models of capital structure, Journal of Financial Economics, 51, 219-244.

Stiglitz, J. (1973). Taxation, corporate financial policy and the cost of capital. Journal of Public Economics, 2, 1-34.

Welch, I. (2006). Common flaws in empirical capital structure research, Working Paper, Brown University. 